\title{
Isolation, structure, and expression of labial, a homeotic gene of the Antennapedia Complex involved in Drosophila head development
}

\author{
Robert J. Diederich, Valerie K.L. Merrill,, ${ }^{1}$ Mary Anne Pultz, ${ }^{2}$ and Thomas C. Kaufman \\ Programs in Molecular, Cellular, Developmental Biology, and Genetics, Department of Biology, Indiana University, \\ Bloomington, Indiana 47405 USA
}

The labial (lab) gene of Drosophila melanogaster is necessary for the proper development of the embryonic (larval) and adult head. We have identified the lab transcription unit within the proximal portion of the Antennapedia Complex (ANT-C) by mapping the molecular lesions associated with chromosomally rearranged $l a b$ alleles. We present its molecular structure, nucleotide sequence, and temporal pattern of expression. In addition, using antibodies generated against a fusion protein, we show that in the embryo the lab protein is distributed in neural and epidermal cells of the procephalic lobe; in a discrete loop of the midgut; and in specific progenitor sensory cells of the clypeolabrum, thoracic segments, and tail region. The regions of lab expression in the developing cephalon represent nonsegmented domains that are anterior to and largely nonoverlapping with the domains of expression of the Deformed $(D f d)$ and proboscipedia $(p b)$ genes, two other homeotic loci of the ANT-C that also function to direct the development of head structures. Furthermore, lab head expression is associated with the complex cellular movements of head involution, a process that not only is defective in labembryos, but the failure of which appears to be largely responsible for the defects observed in mutant embryos. Finally, we suggest that lab head expression provides a molecular marker for an intercalary segment, an ancestral segment that has become morphologically indistinct during the evolution of the insect head.

[Key Words: Antennapedia Complex; Drosophila, head segmentation; homeo box; labial; protein localization]

Received December 7, 1988; revised version accepted January 30, 1989.

The body plan of Drosophila is composed of a repeating array of segments, the identities of which are specified by the activity of homeotic genes. This role has been inferred from genetic analyses: mutations that lead to inactivation or misexpression of a homeotic gene effect the transformation of one segment to the identity of another. Two main clusters of homeotic genes, the Bithorax Complex (BX-C) (Lewis 1978; Sánchez-Herrero et al. 1985) and the Antennapedia Complex (ANT-C) (Lewis et al. 1980a,b; Kaufman et al. 1980) are found in the Drosophila genome. The genes of the BX-C are involved in specifying the identity of thoracic and abdominal segments, whereas the homeotic genes of the ANT-C direct the development of head and thoracic segments (for review, see Mahaffey and Kaufman 1988).

The ANT-C comprises five homeotic genes: Antennapedia (Antp), Sex combs reduced (Scr), Deformed (Dfd), proboscipedia $(p b)$, and labial (lab; V.K.L. Merrill, R.J. Diederich, F.R. Turner, and T.C. Kaufman, in prep.). In addition, genetic analysis has revealed three other loci that function to establish the embryonic body plan.

'Current address: Biology Department, Brandeis University, Waltham, Massachusetts 02154 USA; ${ }^{2}$ Current address: Department of Biological Sciences, Stanford University, Stanford, California 94305 USA.
These include bicoid $(b c d)$, a maternal-effect gene necessary for the specification of the anterior-posterior axis of the embryo (Frohnhöfer and Nüsslein-Volhard 1986); fushi tarazu (ftz), a segmentation gene of the pair-rule class (Wakimoto et al. 1984); and zerknüllt (zen), a zygotically active gene required for dorsal embryonic development (Wakimoto et al. 1984). Molecular analysis has shown that each of the aforementioned genes contains a homeo box domain (McGinnis et al. 1984; Scott and Weiner 1984; Kuroiwa et al. 1985; Doyle et al. 1986; Frigerio et al. 1986; Hoey et al. 1986; Regulski et al. 1987; Berleth et al. 1988; Mlodzik et al. 1988; D. Cribbs, M.A. Pultz, and T.C. Kaufman, in prep.; this paper). An additional homeo-box-containing gene, $z 2$, for which no genetic function is known, also has been discovered within the ANT-C (Rushlow et al. 1987; Pultz et al. 1988). The isolation of $l a b$, described herein, marks the completion of the molecular cloning of the ANT-C. Thus, in this remarkable portion of the Drosophila genome, nine homeo-box-containing genes are clustered within $\sim 330 \mathrm{~kb}$ of contiguous genomic sequence.

The $1 a b$ gene, the most proximal member of the ANT-C, recently has been shown to be necessary for the proper development of the larval and adult head. (A detailed developmental genetic analysis will be presented elsewhere; V.K.L. Merrill et al. in prep.). To summarize, embryos lacking $l a b$ function exhibit a mutant pheno- 
type late in embryogenesis that involves a disruption of the cellular movements associated with head involution. These embryos die at the time of hatching and display grossly aberrant mouthpart structures, although no homeotic phenotype is apparent. However, observations of a hypomorphic allele that produces adult survivors, in conjunction with clonal analysis studies using the technique of somatic recombination, have allowed us to infer a homeotic role for $l a b$ in determining the segmental identity of the adult head: Clones of $l a b$ mutant cells in posterior regions of the head display a duplication of dorsal thoracic tissue. Interestingly, this phenotype is similar to that of $D f d^{-}$tissue (Merrill et al. 1987). Clearly, an understanding of the relationship of $l a b$ and $D f d$ expression, as well as $p b$ expression, will be an essential prerequisite to understanding the genetic control of head development in Drosophila and, perhaps, in insects in general.

In this paper we identify the lab gene within cloned genomic sequences of the ANT-C and present its genomic organization and nucleotide and predicted amino acid sequences. Using antibodies directed against a portion of the $l a b$ protein, we show that $l a b$ is the most anteriorly expressed of the ANT-C homeotic loci and is expressed in domains that are not overtly segmented. We discuss the correlation of $1 a b$ expression with $l a b$ mutant defects and the implications of this expression in furthering our understanding of the segmental organization of the insect head.

\section{Results}

\section{Identification of the lab locus}

The centromere-distal portion of the ANT-C, extending from polytene chromosome bands $84 \mathrm{~A} 4,5$ to $84 \mathrm{~B} 1,2$, was previously isolated in this laboratory as a chromosomal walk (Scott et al. 1983; see also Garber et al. 1983). The breakpoint of the chromosomal rearrangement, $D f d^{R \times 16}$, defined the zero coordinate in these cloned sequences and was later shown to interrupt the $D f d$ transcription unit (Regulski et al. 1987). To characterize molecularly the $l a b$ and $p b$ loci, which prior genetic studies had placed in the proximal ANT-C (Kaufman 1978; Lewis et al. $1980 \mathrm{~b}$ ), we extended the chromosomal walk $60 \mathrm{~kb}$ proximally. Our recent analysis of the $p b$ region spanned the genomic interval -50 to $-110 \mathrm{~kb}$ (Pultz et al. 1988). The remainder of the chromosomal walk, extending to $-144 \mathrm{~kb}$, is shown in Figure 1.

The lab gene was localized within the cloned sequences by physically mapping the breakpoints of chromosomal rearrangements that disrupt $l a b$ function. The cytology, parent chromosomes, and method of isolation of the chromosomal rearrangements mapped in this study are described in V.K.L. Merrill et al. (in prep.) and Pultz et al. (1988). Standard Southern analysis procedures were employed to map breakpoints (Bender et al. 1983). Briefly, $\lambda$ clones and/or plasmid subclones of genomic DNA were hybridized to Southern blots containing restriction enzyme digests of whole-genome DNA from mutant and wild-type (parental) flies. Anomalous restriction fragments, present in the mutant DNA but not the parental DNA, allowed us to identify breakpoint positions (data not shown; see also Methods). The results of the breakpoint mapping are summarized in Figure 1.

A distal boundary for the lab locus is provided by the chromosomal rearrangement, $p b^{\text {map8 }}$, a small deficiency of the $p b$ locus (Pultz et al. 1988) that genetically complements $l a b$ function when heterozygous with $l a b$ deficient chromosomes (e.g., $D f(3 \mathrm{R}) S c r$; Lewis et al., 1980b).

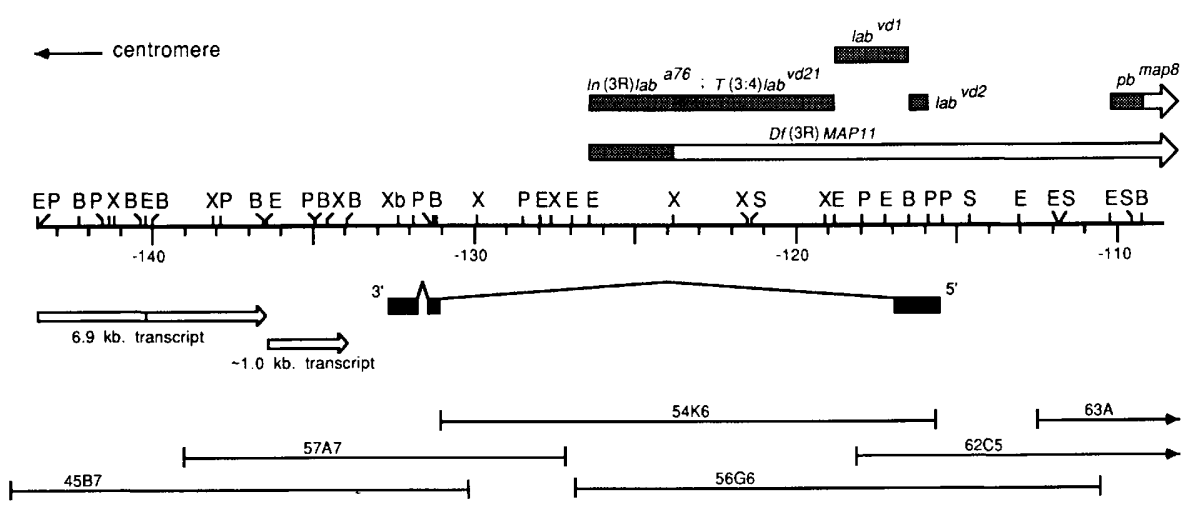

Figure 1. Molecular organization of the lab region of the ANT-C. (Bottom) The overlapping $\lambda$ clones (Canton S DNA) of the chromosomal walk. Phages 63A and $62 \mathrm{C} 5$ are contiguous with the chromosomal walk of the $p b$ region (Pultz et al. 1988); coordinates (kb) provided under the restriction map have been extended proximally. Restriction enzymes: (B) BamHI; (E) EcoRI; $(\mathrm{P})$ PstI; (S) SalI; (X) $X$ hoI; (Xb) Xbal /only one site shown). (Top) The breakpoints of mutant chromosomes, which identify the lab transcription unit. Open boxes represent deleted portions of the genome; cross-hatching indicates the regions of uncertainty. Although cytologically normal, the $l a b^{v d 1}$ and $l a b^{v d 2}$ alleles are associated with a small deletion $(<2 \mathrm{~kb})$ and a transposition (insertion of $\sim 600 \mathrm{bp}$ ), respectively. The parent chromosome (see V.K.L. Merrill et al., in prep.) of the $v d$ alleles of $l a b$ contains a repetitive DNA element within the first intron (at approximately - 119), which appears to be a 'roo' element (Meyerowitz and Hogness 1982; W. Bender, pers. comm.) based on size and restriction sites. The three exons (blackened boxes) of the lab transcription unit are diagramed below the restriction map. Open arrows represent genomic fragments that hybridize to 6.9 - and $\sim 1.0-\mathrm{kb}$ transcripts on Northern blots (direction of transcription indicated). 
The proximal breakpoint of $p b^{\text {map8 }}$ lies at approximately -110 on the molecular map. Another mutant chromosome, $D f(3 \mathrm{R}) M A P 11$, contains a deletion that extends $\sim 15 \mathrm{~kb}$ proximally of the $p b^{\text {maps }}$ end point. $D f(3 \mathrm{R}) M A P 11$ fails to complement $l a b$; thus, the $15-\mathrm{kb}$ interval defined by the proximal breakpoints of $D f(3 \mathrm{R}) M A P 11$ and $p b^{\text {map8 }}$ identifies sequences that are essential for wild-type lab function. Furthermore, all identified breakpoints of lab mutations have been localized within this region.

\section{Molecular structure of the lab locus}

To determine which regions of the $l a b$ locus are active transcriptionally, genomic DNA fragments encompassing $1 a b$ - breakpoints $(-134$ to -110$)$ were hybridized to Northern blots containing RNA from various stages of Drosophila development (data not shown). A $3.0-\mathrm{kb}$ poly $(\mathrm{A})^{+}$transcript was detected with genomic probes situated on either side of the $1 a b^{-}$breakpoints, from positions -134 to -131 and -117 to -113 . These respective regions were also found by Southern analysis (data not shown) to contain sequences that cross-hybridize with the Antp homeo box and the Notch repetitive sequence, opa, or CAA/G repeat (Poole et al. 1985; Regulski et al. 1985; Wharton et al. 1985), both of which are present in all homeotic genes of the ANT-C (Kuroiwa et al. 1985; Regulski et al. 1985, 1987; Pultz et al. 1988; D. Cribbs, M.A. Pultz and T.C. Kaufman, in prep.).

As part of the structural characterization of the $l a b$ transcription unit, we first isolated cDNA clones from a 3- to 12-hr embryonic library (Poole et al. 1985) using a 1.2-kb XbaI-BamHI genomic fragment $(-132.5$ to -131) with homeo box homology as a hybridization probe. Three apparently identical cDNA inserts of $1.7 \mathrm{~kb}$ were recovered and analyzed by restriction enzyme mapping and by hybridization to Southern blots containing restriction digested genomic DNA /cloned and total). One of these cDNAs, E7:G1, was selected for further analysis.

Both strands of the cDNA (E7:G1) and most of the corresponding genomic DNA have been sequenced (Fig. 2). A comparison of these sequences indicated that two introns, $\sim 14 \mathrm{~kb}$ and $\sim 250 \mathrm{bp}$ in length, are spliced from the primary $l a b$ transcript. The homeo box is interrupted by the smaller intron at the approximate juncture of the helix 3 and helix 2 domains (Laughon and Scott 1984). Genomic sequences at all exon/intron boundaries are in excellent agreement with consensus donor [(C/A)AG/GT(A/G)AGT] and acceptor $\left[(\mathrm{T} / \mathrm{C})_{\mathbf{n}} \mathrm{N} / \mathrm{C} /\right.$ T)AG/G] splice junctions (Mount 1982). The only other positions where the cDNA and genomic sequences diverge are at the extreme $5^{\prime}$ and $3^{\prime}$ ends of the cDNA. A stretch of 20 cytosine residues found at the $5^{\prime}$ end is an artifact resulting from the method of construction of the cDNA library (Poole et al. 1985). Twenty-two adenosine residues at the $3^{\prime}$ end, on the other hand, most likely derive from the poly $(A)$ tail of the mature transcript and thus provide a tentative definition of the $3^{\prime}$ end. Two consensus polyadenylation signals (Proudfoot and Brownlee 1976) are present $25-35$ bp upstream from the point where the cDNA and genomic sequences diverge. However, we cannot exclude the possibility that other $3^{\prime}$ termini are used in addition to the one represented by E7 : G1.

Because the cDNA was less than full length, a combination of primer extension and $S 1$ nuclease protection experiments was used to define the $5^{\prime}$ end of the $1 a b$ transcription unit. Preliminary S1 mapping was performed on embryonic poly $(A)^{+}$RNA using singlestranded probes obtained from the adjacent 240-bp SmaI-NcoI and 1.37-kb NcoI genomic fragments (data not shown; Fig. 3). This analysis indicated that the $l a b$ transcription unit was most likely composed of only three exons. A more precise definition of the $5^{\prime}$ end was obtained using a 680-bp PvuII-NcoI genomic fragment; 385 nucleotides were protected from S1 nuclease digestion (Fig. 3). For the primer extension experiment, a 61-nucleotide PvuII-SacII primer (derived from the 680bp fragment) was hybridized to poly $(\mathrm{A})^{+} \mathrm{RNA}$ and extended with reverse transcriptase. A cDNA extension product equal in length to the $S 1$-protected fragment agreed with the S1 analysis and indicated that the transcription start site was $\sim 385$ bp $5^{\prime}$ of the labeled PvuII site (Fig. 3).

We have also sequenced genomic DNA corresponding to that portion of the lab transcript that is not represented in the cDNA. This $5^{\prime}$ region, constituting $40 \%$ of the total transcript length, is inferred from the primer extension and SI nuclease protection experiments (Fig. 3). At the mapped 5' end, we noted a perfect match to a consensus sequence for transcription initiation sites [ATCA/G/T/T/C/T)] compiled from Drosophila and other insect genes (Hultmark et al. 1986); no strong similarity to a consensus splice acceptor site was found in this region. Due to insufficient mapping resolution, we arbitrarily assigned the transcription start site to the first nucleotide of this conserved sequence (position +1 , Fig. 2); in general, mRNA cap sites have been mapped to this nucleotide (Hultmark et al. 1986). Thus, the lab transcript comprises three exons of 1455,416 , and 935 $\mathrm{bp}$, for a total of $2806 \mathrm{bp}$. This is in reasonable agreement with the 3.0-kb length determined by Northern blot analysis; the $\sim 200$-nucleotide difference presumably reflects the contribution of a poly(A) tail (Darnell 1982).

The first ATG codon (position + 239) encountered at the $5^{\prime}$ end of the $l a b$ transcript marks the beginning of the only long open reading frame $\left(O R F \mid\right.$; a $3^{\prime}$ situated homeo box is in-frame with this $1887-$ bp ORF. Two nearby ATG codons may also serve as translational start sites for this reading frame. The first and third ATGs are within a sequence context that closely matches a Drosophila consensus sequence $[\mathrm{ANN} / \mathrm{C} / \mathrm{A} / \mathrm{A} / \mathrm{A} / \mathrm{C})(\mathrm{A} / \mathrm{C}]$ ATGNNN] for translation initiation sites (Cavener 1987). Assuming translation initiates at the first ATG, the predicted lab protein comprises 629 amino acids with a molecular mass of $67.5 \mathrm{kD}$. 
Downloaded from genesdev.cshlp.org on April 26, 2023 - Published by Cold Spring Harbor Laboratory Press

$-292$

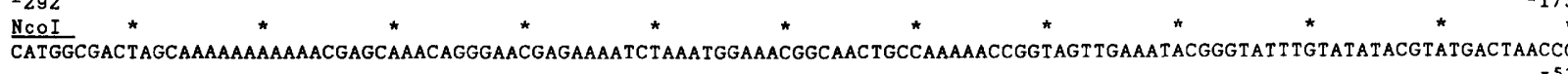

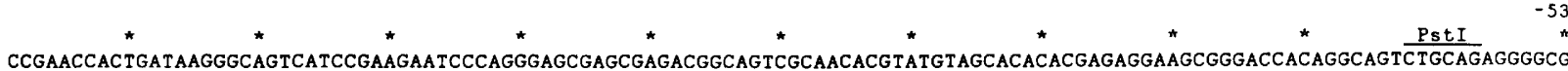
* + +1 * * *

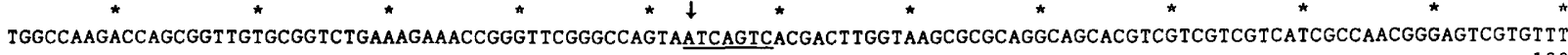

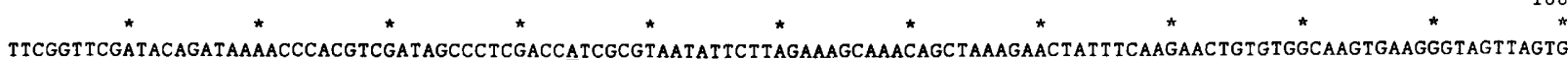

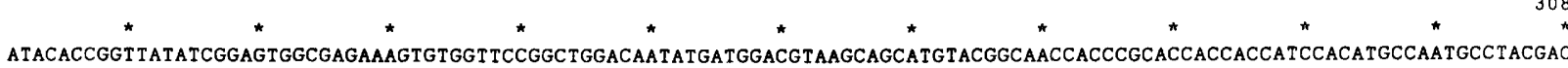
MetMetAspValSerSerMetTyrGlyAsnHisProHisHisHisHisProHisAlaAsnAlatyras

* $\frac{\text { SacII }}{4}$ * * * * * * * *

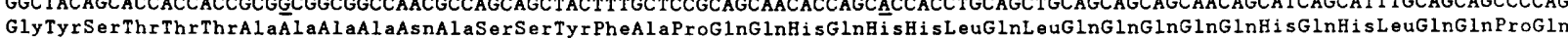
* * * * * * * * * * PvuII * * * * * * * * * GlnHis LeuThrTyrAsnGly TyrGluSerSerSerProGlyAsnTyrTyrProGinglnGlnAlaGlnLeuThrProProProThrSerSerHisGlnValValGlnGinHisGlnGln

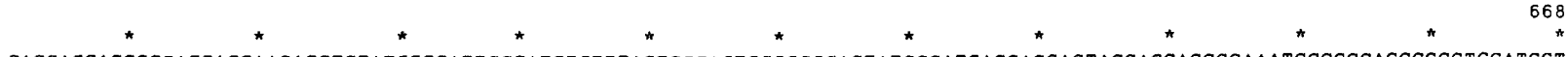
CAGCAGCAGGCGCAGCAGCAACAGCTCTATCCGCATTCGCATCTCTTTAGTCCCAGTGCGGCGGAGTATGGCATCACCACGAGTACGACCACGGGAAATCCGGGCACGCCGCTCCATCCT GlnGlnGlnAlaGlnglnglnglnLeuTyrProHis SerHisLeuPheSerProSerAlaAlagluTyrGlyIleThrThrSerThrThrThrGlyAsnProGlyThrProLeuHisPro

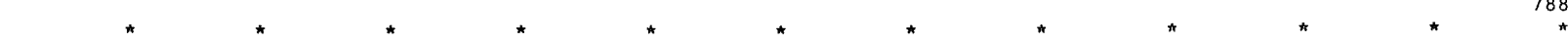
AGTAGCCACTCTCCGGCGGACTCCTACTACGAAAGTGACTCGGTGCACTCGTACTACGCTACCGCCGCAGTGGCCACAGTTGCTCCACCCAGCAATAGCTCACCTATTACCGCCGCCAAT SerSerHis SerProAlaAspSerTyrTyrGluSerAspSerValHis SerTyrTyrAlaThrAlaAlaValAlaThrValAlaProProSerAsnSerSerProIleThrAlaAlaAsn

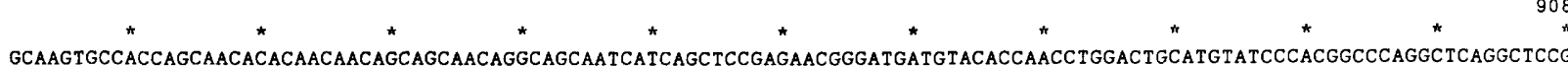
AlaSerAlaThrSerAsnThrGlnGlnGlnGlnGlnGlnAlaAlaI leIleSerSerGluAsnglyMetMetTyrThrAsnLeuAspysMetTyrProThrAlaGinAlaGinAlaPro

* * * * * * * * * * * BamHI * GTTCACGGATATGCCGGCCAGATCGAGGAGAAATACGCCGCCGTCCTGCACGCCAGCTATGCACCCGGAATGGTGCTGGAGGATCAGGATCCAATGATGCAGCAGGCCACGCAGTCGCAG ValHisGlyTyrAlaGlyGlnIleGluGluLy Ty TAlaAlaValLeuHisAlaSerTyrAlaProGlyMetValLeuGluAspGInAspProMetMetGlnGlnAlaThrGlnSerGln

ATGTGGCACCACCAGCAACATCTGGCAGGCAGCTATGCCCTAGATGCCATGGACTCGCTAGGAatgCaCGCCCACATGCATCACGGCCTGCCCCACGGACACCTGGGCAACTIGGCCAAC MetTrpHisHisGlnGInH is LeuAlaGlySerTyrAlaLeuAspAlaMetAspSerLeuGlyMetHisAlatisMetHisHisGlyLeuProHisGlyHisLeuGlyAsnLeuAlaAsn c AATCCGCATCAGCAACAGCCACAAGTCCAGCAGCAACAGCAGCAGCCGCACCAGCAaCCGCAACATCCGCAGAaCCAATCCCCAGCGGCACACCAGCAGCACCACCAGAaCTCCGTGTCG AsnProHisGlnglnglnProGlnValglnglnglnglnGlnglnProHisglnglnProglnHis ProglnAsnglnSerProAlaAlaHisGinglnHisHisGlnAsnSerValSer

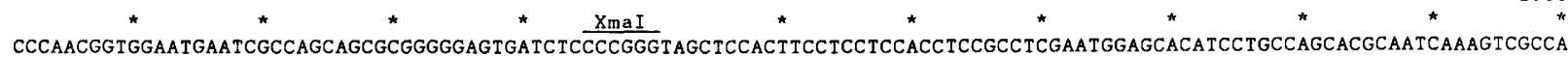
ProAsnGlyGlyMetAsnArgGInGlnArgGlyGlyValI leSerProGlySerSerThrSerSerSerThrSerAlaSerAsnglyAlaHisProAlaSerThrGlnSerLysSerPro

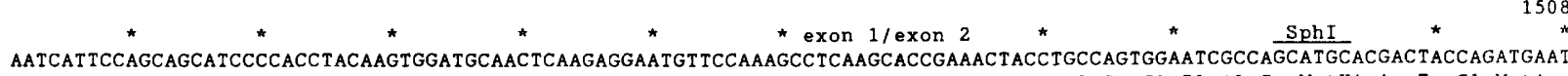
AsnHis SerSerSerIleProThrTyrLysTrpMetGInLeuLysArgAsnValProLys ProGlnalaProLysLeuProAlaSerGiy IeAlaSerMetHisAspTyrGinMetAsn PVuII SacII * * * * * * BamHI XmaI * $\frac{\text { PVuII }}{\text { GGACAGCTGGACATGTGCCGCGGTGGAGGAGGCGGGGCAGCGGCGTCGGGAGCGGTCCCGTGGGCGTTGGGGGCAACGGATCCCCCGGGATCGGAGGCGTCCTITCCGTGCAGAACTCC }} \stackrel{\text { SacII }}{*}$ GlyGlnLeuAspMetCysArgGlyGlyGlyGlyGlyGlySerG lyValGlySerGlyProValGlyValGlyGlyAsnglySerProGly I leGlyGlyValLeuSerValGlnAsnSer

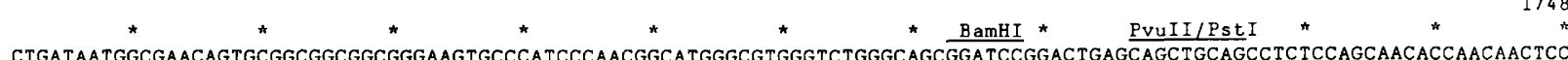
LeuI leMetAlaAsnSerAlaAlaAlaAlaGlySerAlaHisProAsnGlyMetGlyValGlyLeuGlySerGlySerGlyLeuSerSerCysSerLeuSerSerAsnThrAsnAsnSer

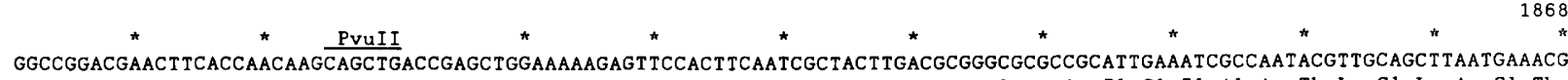
GlyArgThrAsnPheThrAsnLysGlnLeuThrGluLeuGluLysGluPheHisPheAsnArgTyrLeuThrArgAlaArgargI leGluI IeAlaAsnThrLeuGlnLeuAsnGluTh

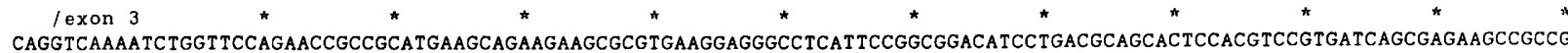
GlnValLysIleTrpPheGInAsnArgArgMetLysGlnLysLysArgValLysGluGlyLeuIleProAlaAspIleLeuThrGlnHisSerThrSerValI leSerGluLys ProPro

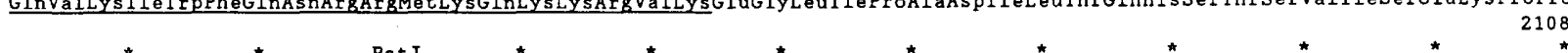
CAGCAGCAGCAGCCACAGCCGCCGGAGCTGCAGTTGAaGTCGCAGGGCAGCGATCTGGGCGGGAatgaGCTGGCCACAGGAGCACCTTCGACACCCACGACAGCCATGACACTGACAGCA GInGInGInGInProGInProProGluLeuGlnLeuLysSerGInGlySerAspLeuGlyGlyAsnGluLeuAlaThrGlyAlaProSerThrProThrThrAlaMetThrLeuThrAla

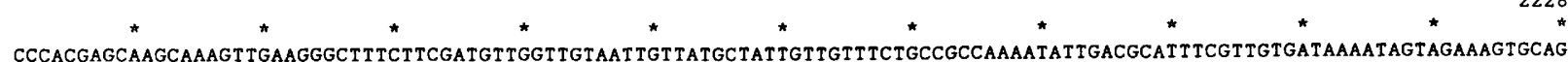
ProThrSerLysGInSerEND

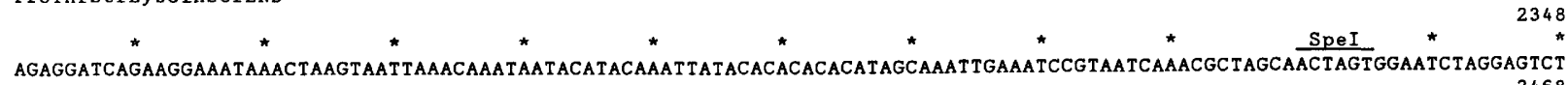
* * * * * * * * * * * * * * * * * *

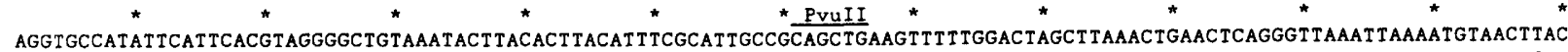

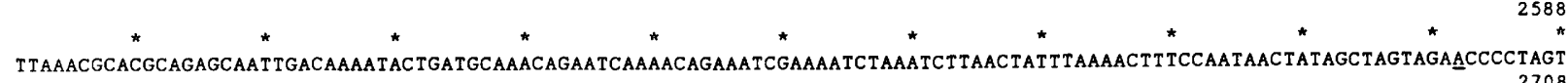
TTAAACGCACGCAGAGCAATTGACAAAATACTGATGCAAACAGAATCAAAACAGAAATCGAAAATCTAAATCTTAaCTATT TAAAACTTTCCAATAACTATAGCTAGTAGABCCCCTAGT

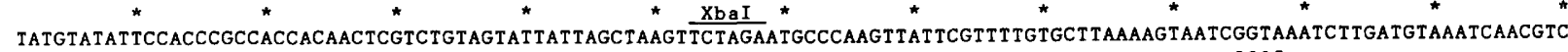

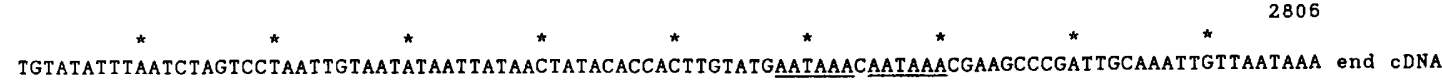

Figure 2. (See facing page for legend.) 


\section{Unidentified transcription units proximal to lab}

In the course of mapping transcriptionally active regions surrounding the $1 a b^{-}$breakpoints, we discovered two additional transcription units just proximal and $3^{\prime}$ to the $l a b$ transcription unit. The absence of any chromosomal rearrangements to provide a proximal boundary for the $l a b$ locus prompted us to investigate these transcribed regions to determine their relationship to the lab transcription unit. Figure 1 shows that two size classes of transcripts of 6.9 and $\sim 1.0 \mathrm{~kb}$ are detected on Northern blots with genomic probes from the -143.5 to -136.5 interval and the -136.5 to -134 interval, respectively (data not shown). Both are transcribed in a proximal to distal direction, opposite that of the 3.0-kb lab transcript (data not shown; see Methods). Thus, these transcripts cannot be alternately spliced products of the lab gene and are unlikely to have a role in lab function.

\section{Temporal expression of lab transcripts}

To determine the temporal profile of $l a b$ transcript accumulation, a Northern blot containing poly(A)+ RNA from staged embryos, larvae, pupae, and adult flies was probed with the 1.7-kb EcoRI insert of the cDNA, E7 : G1 (Fig. 4). A major transcript of $3.0 \mathrm{~kb}$ is first detected at $2-4 \mathrm{hr}$ of embryogenesis, a period that encompasses preblastoderm stages through gastrulation and rapid germ-band elongation. By 6-8 hr of embryogenesis, the level of this transcript has peaked and remains constant through $16-20 \mathrm{hr}$ of development. Just before hatching, $\sim 20-24 \mathrm{hr}$, transcript accumulation diminishes to a level that is roughly maintained throughout the larval stages. Transcript accumulation is very low during the pupal stages and is not detected in adult flies. A second band of hybridization $(1.9 \mathrm{~kb})$, observed early in embryogenesis, most likely represents non-lab-specific hybridization (see legend to Fig. 4).

\section{Preparation of antibodies to a $\beta$-galactosidase/lab fusion protein}

The expression of the $l a b$ protein was examined using polyclonal antibodies generated against a $\beta$-galactosidase/lab fusion protein. To construct the gene fusion, a 1.33-kb XmaI-XbaI fragment of the cDNA, E7 : Gl, was inserted into the plasmid expression vector pWR590-2 (Guo et al. 1984), 3' of truncated bacterial $\beta$-galactosidase coding sequences (encoding $\sim 600$ amino acids). The carboxyl terminus of the hybrid gene derived from the carboxyl-terminal portion of the $1 a b$ gene and encoded 271 of the 629 amino acids (including homeo box domain) that make up the $1 a b$ protein.

The $\beta$-galactosidase $/ 1 a b$ hybrid protein was isolated from bacterial cell extracts on SDS-polyacrylamide gels and used to immunize rabbits. Antibodies specific for the $l a b$ portion of the fusion protein were purified from the immune serum using affinity chromatography (see Methods).

\section{Localization of labial protein during embryogenesis}

The distribution of cells expressing the $l a b$ protein during embryogenesis was examined by staining wholemount preparations of fixed Oregon-R embryos using the affinity-purified antibodies in conjunction with secondary antibodies linked to horseradish peroxidase (HRP) (see Methods). To show that the observed staining pattern was due to the presence of the lab protein, embryos resulting from the cross, $1 a b^{v d-1} / \mathrm{TM} 3 \times 1 a b^{v d-1} /$ TM3, were stained with the $l a b$ antibody. Whereas all embryos of a particular stage stained in wild-type preparations, a significant fraction $(\sim 20 \%)$ of similarly staged embryos from the above cross failed to stain above background levels and was presumed to be homozygous for the $1 a b^{v d-1}$ null allele. Thus, all staining was dependent on $l a b$ gene function and, presumably, the $l a b$ protein.

At $\sim 3 \mathrm{hr}$ postoviposition, the events of gastrulation are initiated in the Drosophila embryo (for a description of embryogenesis, see Turner and Mahowald 1977, 1979; Campos-Ortega and Hartenstein 1985; embryonic stages are based on the latter reference). During the next 20 min the mesodermal primordium, as well as the endodermal primordia of the anterior and posterior midgut, invaginate along the mid-ventral and posterior regions of the embryo. The cephalic furrow appears at this time and roughly delimits the prospective head region, also referred to as the procephalon. The germ band, comprising the mesoderm and overlying ectodermal cell layer, begins to elongate in a posterior direction toward the end of the gastrulation period. During an initial rapid phase (stage $8 ; 3: 10-3: 40 \mathrm{hr}$ ), the germ band extends around the posterior pole of the embryo and proceeds anteriorly. This is followed by a slow period of elongation during which the proctodeum becomes situated adjacent and dorsal to the head segment primordia. It is at the beginning of this slow extension phase (stage 9; $3: 40-4: 20 \mathrm{hr}$ ) that a strong and consistent pattern of lab-expressing cells is first detectable (Fig. 5A,B). A sim-

Figure 2. Nucleotide and predicted amino acid sequence of $l a b$. The nucleotide sequence is a composite of cDNA and genomic DNA sequences obtained from Ore-R and Canton S strains of Drosophila, respectively. The limits of the cDNA (E7: G1) are indicated; corresponding genomic sequence was determined for all but two regions: from position 1568 to the BamHI site at 1701 and from the beginning of the third exon $(1872)$ to the SpeI site at position 2328 . The start of transcription $(+1)$ has been assigned to the first nucleotide of the cap site consensus sequence (underlined; see text and Fig. 3). The homeo box and two possible polyadenylation signals are also underlined. Restriction sites are provided for reference (e.g., Figs. 1 and 3). The positions of introns are indicated, but no intronic sequences are shown. We note seven nucleotide differences (underlined) from the sequence reported recently by Mlodzik et al. (1988). Four of these, at positions $330,376,655$, and 1552, result in amino acid differences (doubly underlined). A fifth, at position 482 , is a silent substitution. In the $5^{\prime}$-untranslated region, a nucleotide difference is noted at position 112 and an extra nucleotide is present in the $3^{\prime}$-untranslated region at position 2580 . Changes at positions 1552 and 2580 are present in both our cDNA and genomic DNA clones and cannot be reconciled with the sequence of Mlodzik et al. (1988). The remaining differences derive solely from genomic sequence (from both laboratories) and may thus reflect strain differences. 
Figure 3. Identification of $l a b$ transcription start site by $\mathrm{S} 1$ nuclease protection and primer extension. (Left) A portion of the genomic map $(-117$ to -114.5 ; Fig. 1) containing the first exon. The blackened box indicates extent of the cDNA (E7:G1). $(a, b)$ Genomic DNA fragments used in preliminary S1 nuclease protection experiments (data not shown). Asterisk indicates $5^{\prime}$-end-labeling with ${ }^{32} \mathrm{P}$. (Right) Autoradiograph of the size-fractionated products of the nuclease protection (lanes 1-4) and primer extension (lanes 6,7) reactions. (Lane 1) The 680-nucleotide $P$ vulI-NcoI end-labeled fragment $(c)$ without added RNA or S1 nuclease. (Lanes 3,4) A fragment of $\sim 385$ nucleotides (arrow) protected from nuclease digestion after hybridization to 0-6 hr (lane 3) and 18-23 hr (lane 4) poly(A) ${ }^{+}$embryonic RNA (for details, see Methods). Lane 2 is the same as lanes 3 and 4 except poly(A)- RNA was
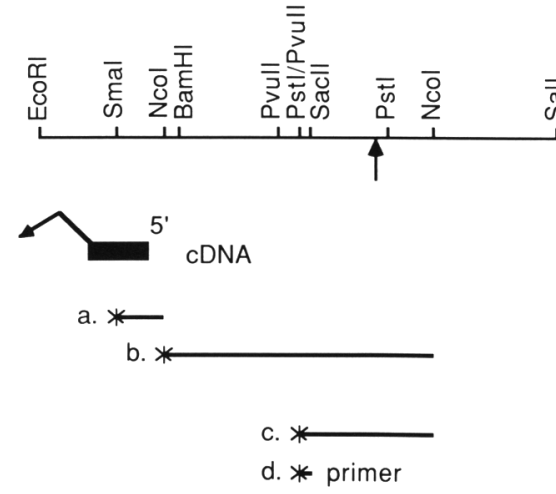

200 bp.

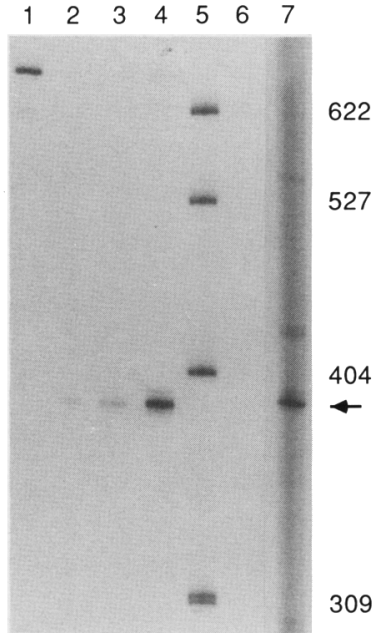
used [faint band represents contaminating $\operatorname{poly}(\mathrm{A})^{+}$ RNA]. (Lane 5) Size markers consisting of end-labeled HpaII fragments of pBR322. (Lane 7) The products of the primer extension reaction using fragment $d$ as primer on 18- to 23-hr poly $(\mathrm{A})^{+}$embryonic RNA. An extension product of $\sim 385$ nucleotides represents the distance from the end of the primer $(P v u I I$ site, +386 , Fig. 2) to the transcription start site (arrow at left; +1 , Fig. 2). Minor extension products present in the primer extension reaction most likely reflect cross-hybridization of the G/C-rich $(69 \%)$ primer to other transcripts, rather than alternately initiated products from the $l a b$ transcription unit. (Lane 6) The primer extension reaction using poly(A)- RNA as template.

ilar pattern (not shown) of much less intensity can be seen earlier, during stage 8 , depending on the sensitivity of the staining technique employed (see Methods).

Throughout embryogenesis, lab expression is confined to derivatives of the ectodermal and endodermal germ layers. At early germ-band-extended stages, the $1 a b$ protein is detectable within cells of the invaginating posterior midgut primordium and in a unique pattern along the lateral and ventral aspects of the procephalon (Fig. 5A,B). From lateral positions on either side of the procephalon, $l a b$-expressing cells extend along the anterior lip of the cephalic furrow and proceed ventroanteriorly to form a V-shaped pattern, the apex of which is at the stomodeal plate (presumptive stomodeum) on the ventral surface. A cluster of more faintly staining cells

Figure 4. Northern analysis of $l a b$ expression. Poly $(A)^{+}$RNA (10 $\mathrm{\mu g} / \mathrm{lane})$ isolated from developmentally staged animals was electrophoretically fractionated, blotted, and hybridized with the ${ }^{32} \mathrm{P}$-labeled insert of the cDNA E7 : G1. A single-size class transcript of $3.0 \mathrm{~kb}$ was detected with this probe and other probes of genomic DNA fragments (not shown) from -134 to -131 and -117 to -113 (Fig. 1). The 1.9-kb band of hybridization most likely reflects non-lab-specific hybridization. This conclusion is based primarily on the observation that the ratio of autoradiographic signals obtained for the $1.9-$ and $3.0-\mathrm{kb}$ bands is reversed when the Northern blot is washed at moderate $\left(0.5 \times \mathrm{SSC}, 0.5 \% \mathrm{SDS}, 65^{\circ} \mathrm{C}\right)$ versus high $(0.1 \times \mathrm{SSC}, 0.5 \%$ SDS, $65^{\circ} \mathrm{C}$ ) stringency conditions (data not shown). The same blot was rehybridized with ribosomal protein 49 gene sequences (rp 49; O'Connell and Rosbash 1984) as a control for hybridization. The first eight lanes contain embryonic RNA (in hrs after egg laying); (L1, L2) first and second instar larvae; (L3-1, L3-2) first and second days of third instar larvae; (P1-5) 5 days of pupation; (adult) male and female flies.
(Fig. 5B), just posterior to the stomodeum, constitutes the previously invaginated anterior midgut rudiment. As cells of the stomodeal plate invaginate, the ectodermal cells expressing $1 a b$ spread laterally, presumably as a result of a broadening of the stomodeal opening. Initially, a thin strip of $l a b$-expressing cells along the ventral lip of the stomodeum connects the lateral lab-expressing regions (Fig. $5 \mathrm{C}$ ), but this connection disappears by stage 11 (Fig. 5D). The cells that make up this 'bridge' are distinct from the anterior midgut primordium and they either do not invaginate into the developing foregut or cease expressing detectable levels of $l a b$ protein upon involuting. Accompanying this ventral change in pattern is a modification of the expression pattern of cells on the lateral aspect of the procephalon. These cells

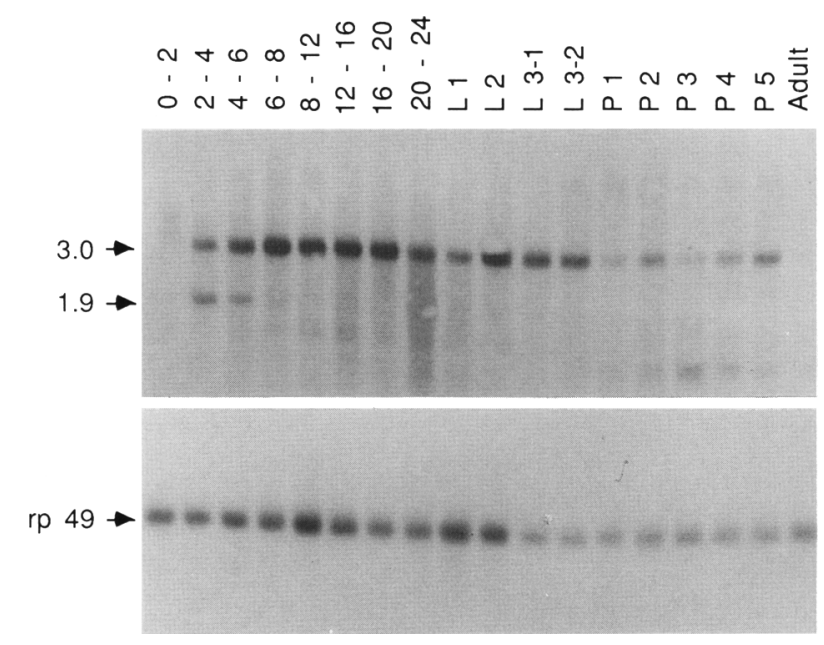



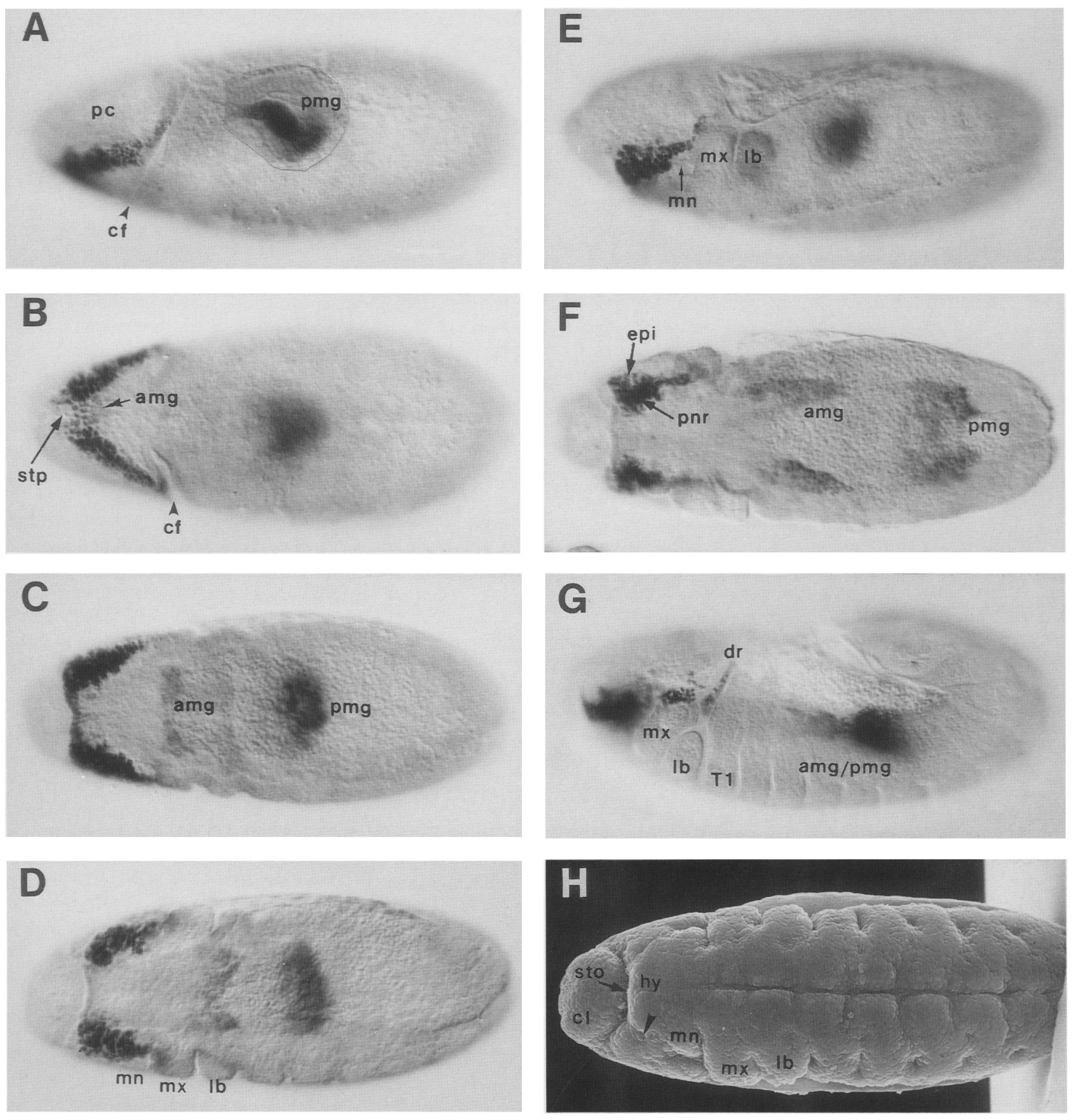

Figure 5. Expression of lab during stages 9-12 of embryogenesis. Embryos are oriented so that anterior ends point left. (A) Lateral view of a stage- 9 embryo during germ-band extension. The posterior midgut rudiment (pmg) is shown in a different focal plane (composite photo) from the rest of the embryo. $(B)$ A ventral view of the same embryo as in $A$. Notice that the unique pattern of lab-expressing cells in the procephalon (pc) highlights the boundary between procephalon (future procephalic lobe and clypeolabrum) and gnathocephalon (future mandibular, maxillary, and labial lobes) before it is morphologically recognizable [(cf) cephalic furrow]. The anterior midgut rudiment (amg) stains faintly [(stp) stomodeal plate). (C) A late stage-10 embryo shown in ventral view. The stomodeum (ectoderm) has invaginated and is contiguous with the caudally migrating anterior midgut rudiment (endoderm). Note the transient strip of $l a b$-expressing cells at the ventral lip of the stomodeum (sto). $(D, E)$ The same embryo (stage 11 ), shown in ventral and lateral views, respectively. Segmentation is apparent; there is no detectable lab expression in the mandibular (mn), maxillary (mx), or labial (lb) lobes or in the prospective hypopharynx (hy). Any apparent staining in these structures (e.g., labial lobes) simply reflects staining in underlying tissues (e.g., anterior midgut). A SEM of a stage-11 embryo $(H)$ is shown for comparison: An arrowhead marks the boundary between hypopharynx and procephalic lobe [(cl) clypeolabrum]. (F) A late stage-11 embryo, ventral view. Presumptive neural (pnr) and epidermal (epi) cells expressing $l a b$ are distinguishable. $(G)$ The anterior and posterior midgut rudiments are fusing in this germ-band-retracting embryo (stage 12, lateral view). lab expression is detectable in the dorsal ridge (dr) and becomes discontinuous in the procephalic lobe. (T1) First thoracic segment. 
begin aggregating near the edges of the stomodeal opening, trailing off posteriorly to a row approximately two cells wide at the level of the vanishing cephalic furrow (Fig. 5E).

With the onset of segmentation in the germ band (stage $11 ; 5: 20-7: 20 \mathrm{hr}$ ), the previously nondescript procephalon is provided with morphological boundaries that clearly delimit the regions of lab expression in the head. In particular, the procephalon subdivides into a morphologically distinct procephalic lobe and clypeolabrum, and the gnathocephalon, comprising the mandibular, maxillary, and labial lobes, also appears at this time. A comparison of the antibody-stained embryos of Figure 5, D and $\mathrm{E}$, with the scanning electron micrograph (SEM) of a comparably staged embryo in Figure $5 \mathrm{H}$ reveals that $l a b$ expression is limited to the anteroventral-most regions of the procephalic lobe; no detectable expression is observed ventrally in cells of the prospective hypopharynx or in cells of the mandibular, maxillary, and labial lobes.

The events of germ-band shortening (stage 12; 7:20-9:20 hr), up until the initiation of mouth and head involution (stage $13 ; 9: 20-10: 20 \mathrm{hr}$ ), bring about a restructuring of the embryonic body plan and a concomitant differentiation of cells expressing the lab protein. Prior to germ-band retraction, both the anterior and posterior midgut primordia assume a bilobate shape and begin migrating toward the posterior pole of the embryo (Fig. 5B-F). As the germ band shortens, these primordia meet midway and fuse, forming a continuous midgut primordium (Figs. 5G and 6A,C). During subsequent development, these cells will constitute an epithelial layer that gradually encircles the yolk sac to produce a closed midgut (Fig. 6F). However, lab expression is restricted to a discrete portion of the midgut, in a band approximately seven cells wide; this translates to a discrete loop of the midgut late in embryogenesis (stage 17; Fig. 7E,F).

Also during germ-band shortening, lab expression becomes detectable in cells of the incipient dorsal ridge (Figs. 5G and 6B). Located laterally over each labial lobe, the dorsal ridges elongate to become continuous across the dorsal midline (Fig. 6B,D). The fusion of the dorsal ridges to form the dorsal fold signals the beginning of the head involution process (stages 14-16, described below).

Coincident with the above changes in the midgut and dorsal ridge, the $l a b$-expressing cells of the procephalic lobe can be observed differentiating into cell populations of epidermal and neural fate. At the extreme anteroventral edges, two intensely staining (bilateral) clusters of cells have begun delaminating from the ectodermal surface (Fig. 5F). During subsequent development, the two clusters become distinct from the overlying ectoderm as they incorporate into a region of the developing central nervous system (CNS) that corresponds to the juncture of the supraesophageal and subesophageal ganglia (Figs. $6 \mathrm{C}$ and $7 \mathrm{~A}, \mathrm{~B}, \mathrm{E})$. This region of the CNS extends around the developing foregut and thus accounts for the bilateral expression pattern in the CNS.

The $l a b$-expressing cells that remain associated with the epidermis of the procephalic lobe form two discon- tinuous cell aggregates during stage 12 (Figs. 5G and $6 \mathrm{~A}, \mathrm{~B})$. The anterior group of cells is difficult to discern due to the intense staining of the underlying cells of the CNS. Posteriorly, a second cluster of epidermal cells is bounded by the dorsal ridge posteriorly, the maxillary lobe ventrally, and the optic lobe primordium loptic plaque) dorsally. The involuting optic plaques cause a local deformation of the procephalic lobe so that these cells appear recessed from the lateral surface, yet do not themselves involute with the optic plaques (Fig. 6B,G and see below).

The morphogenetic movements that characterize atrium (the apparent mouth) formation and head involution are conspicuous features of the later stages of embryogenesis (stages 14-16; 10:20-16hr). The increasing complexity observed in the pattern of $1 a b$ expression in the embryonic cephalon during this time is a direct reflection of the complexity of these movements. The SEMs of Figures 6 and 7 illustrate these events and provide a reference for understanding the evolving pattern of $l a b$ expression in the head.

As the labial lobes move toward the ventral midline and fuse, the maxillary and mandibular appendages rotate dorsoanteriorly and merge with the procephalic lobe; segmental boundaries separating these structures also become less distinct (Fig. $6 \mathrm{H}$ ). The distortion of the procephalic lobe by these merging structures unites the $l a b$-expressing cell clusters of the procephalic lobe into a single arch-shaped pattern (Fig. $6 \mathrm{D}, \mathrm{E}$ ). As the fused mandibular and maxillary lobes continue their anterior migration, they protrude on either side of the caudally retracting clypeolabrum (Fig. 7G). These movements cause a further modification in the arc of $l a b$-expressing cells: The vertical crescent of cells at the lateral edges of the stomodeum (Fig. $6 \mathrm{E}, \mathrm{H}$ ) shifts dorsally to a near horizontal position (Figs. 6F and 7G), whereas those cells constituting the posterior end of the arc (Fig. $6 \mathrm{D}, \mathrm{H})$ extend ventrally into the region between the first thoracic segment $(\mathrm{T} 1)$ and the advancing mandibular/maxillary lobes (Fig. 7A,D,H).

Coincident with the anterior movement of the gnathocephalic appendages, the dorsal fold begins migrating anteriorly over the procephalic lobe to form the dorsal sac (Fig. 7G-I). During this time, the lab-expressing cells at the leading edge of the dorsal fold become continuous laterally with the $1 a b$ - expressing cells at the lateral margins of the procephalic lobe (Fig. 7A-C). Moreover, the gradual retraction of the clypeolabrum and procephalic lobe simultaneously draws the lab-expressing cells of the procephalic lobe deeper into the atrial cavity where they incorporate into the lateral aspects of the dorsal (frontal) sac (Fig. 7E). Late in head involution the mandibular/maxillary lobes rotate anteromedially to assume their final position at the extreme anterior end of the embryo (Fig. 7I). As a result of this movement, the lab-expressing cells situated between the mandibular/ maxillary lobes and T1 (Fig. 7D) shift to a horizontal position that is roughly parallel to the long axis of the embryo (Fig. 7E).

In contrast to the clusters of $1 a b$-expressing cells 

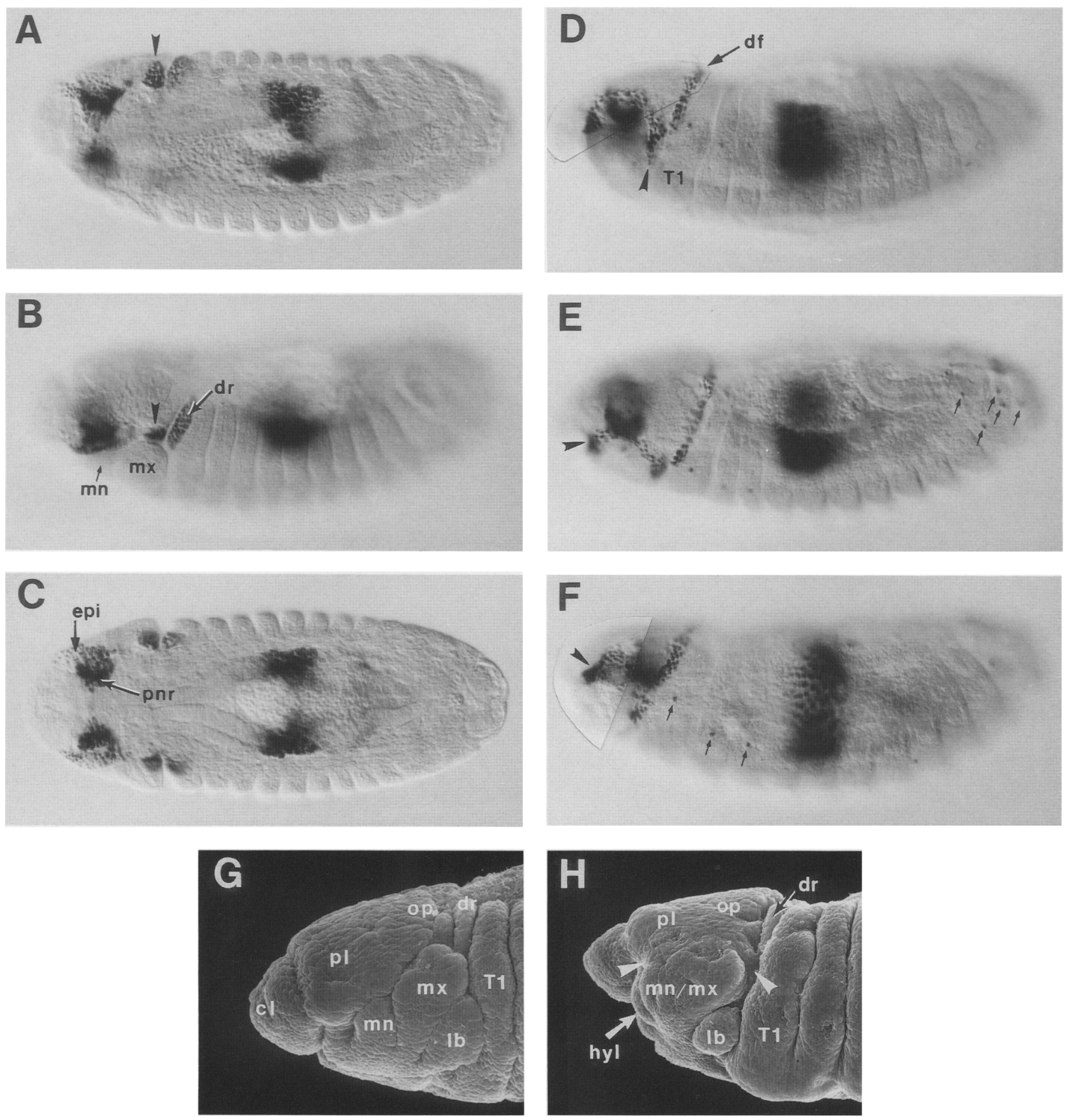

Figure 6. Expression of $l a b$ during stages $12-15$ of embryogenesis. $(A-C)$ Ventrolateral, lateral, and ventral views, respectively, of the same embryo (late stage 12/early stage 13). The SEM in $G$ is provided for comparison. Arrowheads point to a second aggregate of $1 a b$-expressing epidermal cells just ventral to the optic lobe primordium (op). Intensely staining neural cells (pnr) have delaminated from the ectodermal surface. $(D, E)$ Ventrolateral and dorsolateral views, respectively, of the same embryo (early stage 14$)$ at the beginning of head involution ( $D$ is a composite photo of differing focal planes). A SEM in $H$ is shown for comparison; arrowheads indicate extent of arc of lab-expressing cells in the procephalic lobe (pl); (Idf) dorsal fold; (hyl) hypopharyngeal lobes]. (F; composite photo) Lateral view of a late stage-14/early stage-15 embryo. lab-expressing cells situated near the stomodeal opening (arrowhead) have shifted dorsally. Note their position (arrow) in the SEM of a comparably staged embryo shown in Fig. 7G. Small arrows $(E, F)$ indicate $l a b$ expression in presumptive progenitor sensory cells of the tail region $(E)$ and the thoracic segments $(F$; the dorsal complement of cells are out of the plane of focus). All other abbreviations are as in Fig. 5. 
found in the midgut, CNS, and procephalic epidermis, the $l a b$ protein is also detectable within individual epidermal cells of the clypeolabrum, all three thoracic segments, and segments that compose the tail region. The location of these cells suggests that they are progenitors of sensory organs. Moreover, the time at which the lab protein becomes detectable within these cells /stages 13-14) correlates with the time at which progenitor sensory cells become visible in the epidermis (Campos-Ortega and Hartenstein 1985; Hartenstein 1988). On the ventral surface of the clypeolabrum (Fig. 7B,E), a pair of $l a b$-expressing cells corresponds to the position of pro-
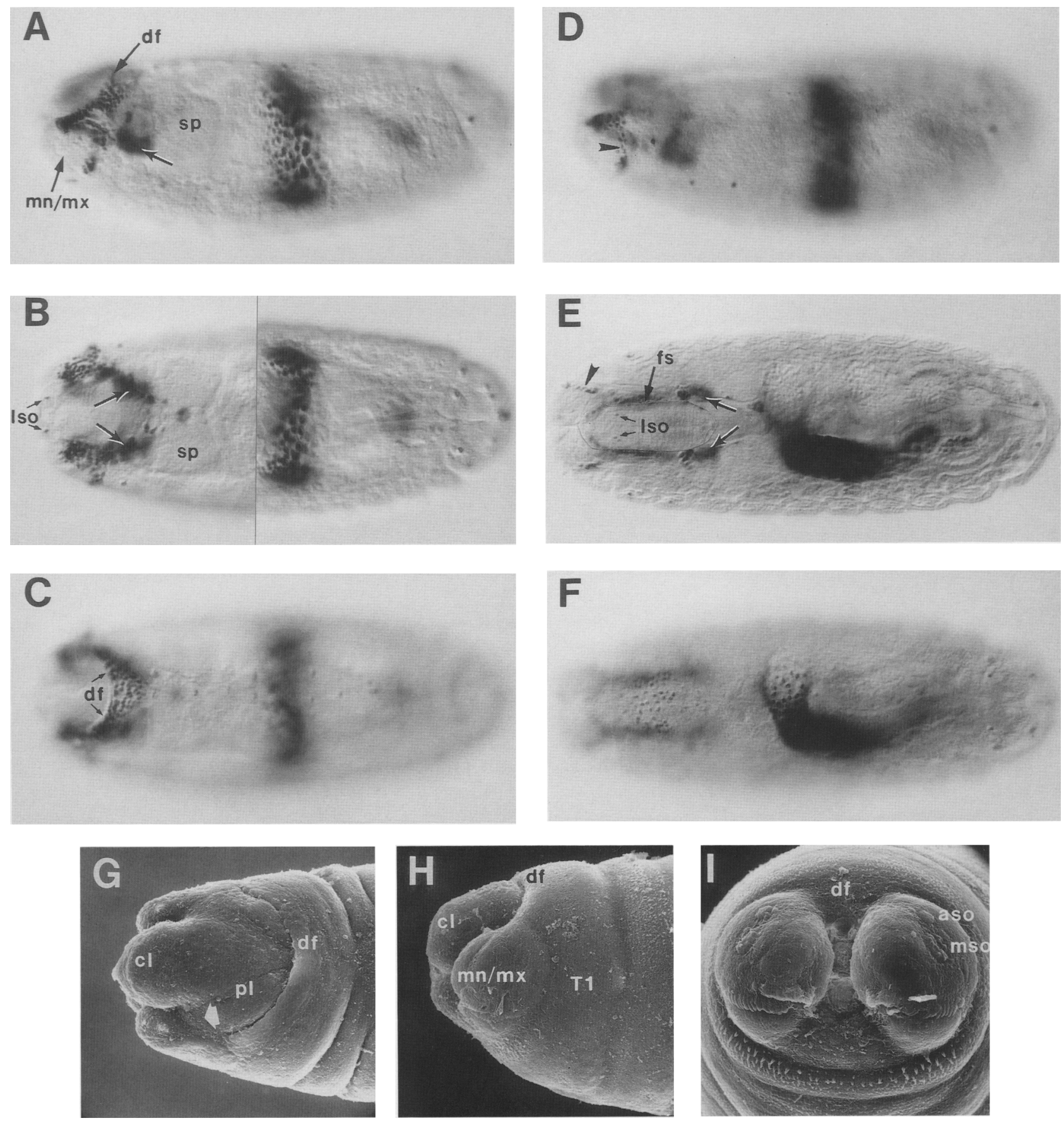

Figure 7. (See facing page for legend.) 
genitor cells of the labral sense organ (epiphysis; Turner and Mahowald 1979; Campos-Ortega and Hartenstein 1985). Likewise, a pair of staining cells on each of the three thoracic segments (Figs. 6D-F and 7D) most likely corresponds to the black dot organs, sensory structures unique to these segments (Campos-Ortega and Hartenstein 1985). Finally, a symmetrical pattern of 10 lab-expressing cells occurring on the eighth abdominal segment and anal plate (Figs. $6 \mathrm{E}$ and $7 \mathrm{~B}$ ) is suggestive of presumptive sensory cells of the larval tail region (Campos-Ortega and Hartenstein 1985; Jürgens 1987; Hartenstein 1988).

\section{Discussion}

We have identified the lab locus within the chromosomal walk of the ANT-C by mapping the molecular lesions associated with chromosomally rearranged $l a b$ alleles. Two such (null) alleles, $T(3: 4) \mid a b^{\text {vd21 }}$ and $\operatorname{In}(3 \mathrm{R}) 1 a b^{a 76}$, break within the first intron of an $\sim 17-\mathrm{kb}$ homeo-box-containing transcription unit and thus identify this as the $l a b$ transcription unit (Fig. 1). In addition, two cytologically normal alleles also reveal molecular lesions: $l a b^{\text {vd1 }}$ is associated with a small deletion $(<2 \mathrm{~kb})$ at the first intron/exon boundary, and $l a b^{\text {vd2 }}$ with a transposition ( $\sim 600 \mathrm{bp}$ ) into the first exon (Fig. 1).

Using heterologous, homeo-box-containing DNA probes others have isolated genomic clones, F90-2 (Hoey et al. 1986) and F24 (Mlodzik et al. 1988), which map cytologically to the vicinity of the proximal ANT-C. Through our recent analysis of this region, we have been able to identify the $l a b$ and $p b$ (Pultz et al. 1988) loci within a portion of a chromosomal walk that includes all loci of the ANT-C $(\sim 330 \mathrm{~kb})$. We confirm that the homeo-box-containing transcription unit associated with F90-2 and F24 is the lab gene. Though our structural analysis agrees well with Mlodzik et al. (1988), we do note several differences in the nucleotide and amino acid sequences (see Fig. 2). Most of these changes are likely to represent polymorphisms between the two different strains (ORE-R and Canton S) of Drosophila used in these studies. Additionally, Mlodzik et al. (1988) present evidence for differential RNA splicing at two splice acceptor sites positioned 18 nucleotides apart at the first intron/second exon junction. Although our analysis did not address this question, our sequence data in this region (not shown) are in agreement with their observation. Finally, we note that the $l a b$ and $p b$ homeo boxes (D. Cribbs, M.A. Pultz, and T.C. Kaufman, in prep.) have a very similar genomic structure: Both are interrupted by a small intron at an identical splice junction position. In this regard, the proximally situated $1 a b$ and $p b$ genes are similar to the engrailed (en) (Poole et al. 1985) and invected genes (Coleman et al. 1987), two genes whose homeo boxes are also interrupted by an intervening sequence at an identical location (but at a position different from that of $l a b$ and $p b \mid$.

\section{Correspondence of lab expression and lab mutant defects in the larva}

It is difficult to reconcile the pattern of $l a b$ expression in the embryonic cephalon with the defects observed in mutant larvae (described in V.K.L. Merrill et al., in prep.), based on a strict interpretation of fate mapping data (generated by laser ablation) for structures of the larval head (Jürgens et al. 1986). The lab gene received its name based on the presumed segmental origin (labial lobes; Campos-Ortega and Hartenstein 1985; Jürgens et al. 1986) of two conspicuously absent head structures (salivary glands and H-piece bridge) in mutant larvae. We were therefore surprised to find no detectable expression of $l a b$ in the labial lobes (Fig. 5D,E) or, in the remaining gnathocephalic appendages, as these also presumably contained the progenitors of other structures defective in $1 a b^{-}$larvae [ventral arms, dorsolateral papilla of terminal sense organ, and $\mathrm{H}$-piece lateral bars; Jürgens et al. 1986]. Although it is possible that the $1 a b$ protein accumulates in progenitor cells of the gnathocephalon and then dissipates from these cells at the time of segmentation, this does not appear to be the case. Based on a study by Technau and Campos-Ortega (1985 cf. Figs. 4, 9, and 13), both the lack of lab expression in the gnathocephalon and its presence in the CNS and along the lateral limits of the procephalic lobe are entirely consistent with the fate of the earliest lab-expressing cells located along the anterior margin of the cephalic furrow (not shown and Fig. 5A; cf. Fig. 7, Mlodzik et al. 1988). Thus, $l a b$ is not expressed in either the progenitor cells of the gnathocephalon or in the visibly segmented gnathal lobes.

Figure 7. Expression of $l a b$ during stages $15-17$ of embryogenesis. $(A-C)$ Dorsolateral, dorsomedial, and dorsal surface views of the same stage-15 embryo. For comparison, the embryos pictured in $G$ and $H$ are slightly younger and older, respectively, than the embryo displayed in $A-C$. Note the position of lab-expressing cells relative to the concerted movements of head structures during head involution. Arrows indicate the location of $l a b$-expressing regions of the CNS [(sp) supraesophageal ganglion]. The nuclear localization of the lab protein is especially pronounced in the large midgut nuclei. Note also in $B$ (composite photo), the lab protein in cells of the labral sense organ (lso) and in presumptive progenitor sensory cells of the tail region. $(D)$ Dorsolateral view of a late stage-15/early stage-16 embryo. Arrowhead points to lab-expressing cells between fused mandibular (mn)/maxillary (mx) lobes and $\mathrm{T} 1$; compare to earlier positions (arrowheads) shown in Fig. 6A,B,D. ( $E$; composite photol Dorsomedial view of a stage-17 embryo during final stages of head involution. The SEM in $I$ (head-on view) is shown for comparison [(aso) antennal or dorsal sense organ; (mso) maxillary or terminal sense organ]. lab-expressing cells are now part of the frontal sac (fs). Arrows point to expression in CNS. Arrowhead marks new position of cells (cf. $D$, arrowhead) resulting from rotation of the mandibular/maxillary lobes (shown in $I$ ). (F) Same embryo as in $\mathrm{E}$, dorsal surface view. The lab protein is evident in widely spaced nuclei of the dorsal pouch; compare with earlier expression in dorsal fold [(df) C]. 
It therefore appears that the head defects observed in mutant larvae are largely the result of secondary effects due to a failure of head involution (V.K.L. Merrill et al., in prep.). The majority of $l a b$-expressing cells of the procephalic lobe are poised at critical junctures with respect to the cellular movements that constitute this complex process. Thus, the fusion of the mandibular and maxillary lobes with the procephalic lobe, the retraction of the clypeolabrum and procephalic lobe, and the simultaneous formation of the dorsal pouch are events in which there is a convergence of lab-expressing cells (stages 14/15, Figs. 6 and 7). These same features of head involution are also defective in $1 a b^{-}$embryos (cf. V.K.L. Merrill et al., in prep.). Implicit in this observation is a role for $l a b$ in mediating, either directly or indirectly, the cell-cell interactions that are essential for the process of head involution and perhaps also for the terminal differentiation of head structures. Whereas a direct role might include regulating the expression of genes encoding cell-surface proteins, an indirect role would manifest itself as a general disruption due to an alteration of segmental identity. An indirect role appears likely and is supported by the observation that a similar lack of correspondence occurs between the pattern of $D f d$ expression and a subset of structures (dorsal sense organ and the dorsolateral and dorsomedial papillae of the terminal sense organ) absent in $D f d$-null embryos, which also fail in head involution (Merrill et al. 1987; Regulski et al. 1987). These structures derive, or are presumed to derive, from the antennal segment of the procephalic lobe (Turner and Mahowald 1979; Frederick and Denell 1982; Jürgens et al. 1986); however, $D f d$ expression is restricted to the gnathocephalon (Chadwick and McGinnis 1987; Martinez-Arias et al. 1987; Jack et al. $1988 ;$ R. Diederich, unpubl.) and is not detectable in the procephalic lobe (except in the dorsal ridge, discussed below). Thus, a disruption of the cellular interactions implicit in the movements of head involution probably accounts for at least a portion of the defects observed in head structures of $l a b^{-}$and $D f d^{-}$embryos and in embryos subjected to the laser ablation studies of Jürgens et al. (1986).

The $l a b$ protein accumulates to high levels in a portion of the midgut in accordance with observations of in situ localized mRNA (Hoey et al. 1986, Mlodzik et al. 1988; and R. Diederich, unpubl.). However, gross microscopic examination of mutant embryos reveals no defects: Fusion of the anterior and posterior midgut primordia and subsequent constrictions of the midgut proceed (apparently) normally. Thus, the significance, if any, of $l a b$ protein accumulation in the midgut remains to be determined.

\section{Correspondence of lab embryonic expression and lab mutant defects in the adult}

Although a direct role for $l a b$ function in embryogenesis is apparently obscured by mutant perturbations of head involution, $l a b$ appears to be involved in determining the segmental identity of the adult head /V.K.L. Merrill et al. in prep.). Moreover, based on their mutant defects, both $l a b$ and $D f d$ have similar roles in imaginal development: Both show considerable overlap in the tissues affected and in the type of homeotic transformation produced (V.K.L. Merrill et al. 1987, and in prep.). We were therefore curious to see whether there was a corresponding overlap in the expression of $l a b$ and $D f d$ in the embryo. During early stages of embryogenesis there appears to be no overlap in cells expressing the $l a b$ and $D f d$ proteins (Mahaffey et al. 1989); $D f d$ expression is restricted to the presumptive gnathocephalon, whereas $l a b$ is limited to the presumptive procephalon. However, by stage 12 , both $l a b$ (Figs. $5 \mathrm{G}$ and $6 \mathrm{~B}$ ) and $D f d$ (Chadwick and McGinnis 1987; Jack et al. 1988; R. Diederich, unpubl.) expression is apparent in cells of the dorsal ridge, although it is not known whether they are expressed in the same cells. Beginning early in head involution this pattern (Figs. 6 and 7; unpubl.) changes quickly so that, while both gene products become localized within cells of the frontal sac, lab displays a broader and more extensive expression pattern in this structure. The use of double-labeling techniques should address whether $l a b$ and $D f d$ are expressed in the same cells. Nonetheless, the coincidence of $l a b$ and $D f d$ expression in the frontal sac, from which the eye-antennal discs arise (Chen 1929), is consistent with their shared roles in the development of the adult head capsule. Indeed, $D f d$ RNA (Chadwick and McGinnis 1987; Martinez-Arias et al. 1987) and protein (R. Diederich, unpubl.) products accumulate in the eye-antennal discs. Based on its adult mutant phenotype and temporal profile of transcript accumulation, it is reasonable to expect that $l a b$ will also be expressed in imaginal tissue, in particular, the eyeantennal discs. To this end, we are currently studying $l a b$ expression in postembryonic stages of development.

\section{Evolutionary considerations}

The segmental organization of the insect head has been the subject of much debate. Present views, strengthened by studies in comparative embryology (reviewed in Anderson 1972, 1973; Rempel 1975) and, more recently, by gynandromorph fate mapping data in Drosophila (Struhl 1981), suggest that the insect head comprises six segments and a nonsegmented acron (see also Jürgens et al. 1986). The controversy centers on the procephalon: Although not obviously segmental, it is thought to include vestiges of intercalary (pre-mandibular), antennal, and labral (pre-antennal) segments (see Fig. 8). Increasingly, molecular data will be pivotal in revealing what morphological information obscures. Indeed, it appears that the pattern of en expression in the epidermis and CNS of the head can be used as a molecular marker for these ancestral segments (Dinardo et al. 1985). The expression patterns of other segmentation genes, such as wingless (Baker 1987, 1988) and gooseberry, (Baumgartner et al. 1987) promise to be useful markers also.

We suggest that the pattern of $1 a b$ expression in the head identifies remnants of an intercalary segment. Sev- 

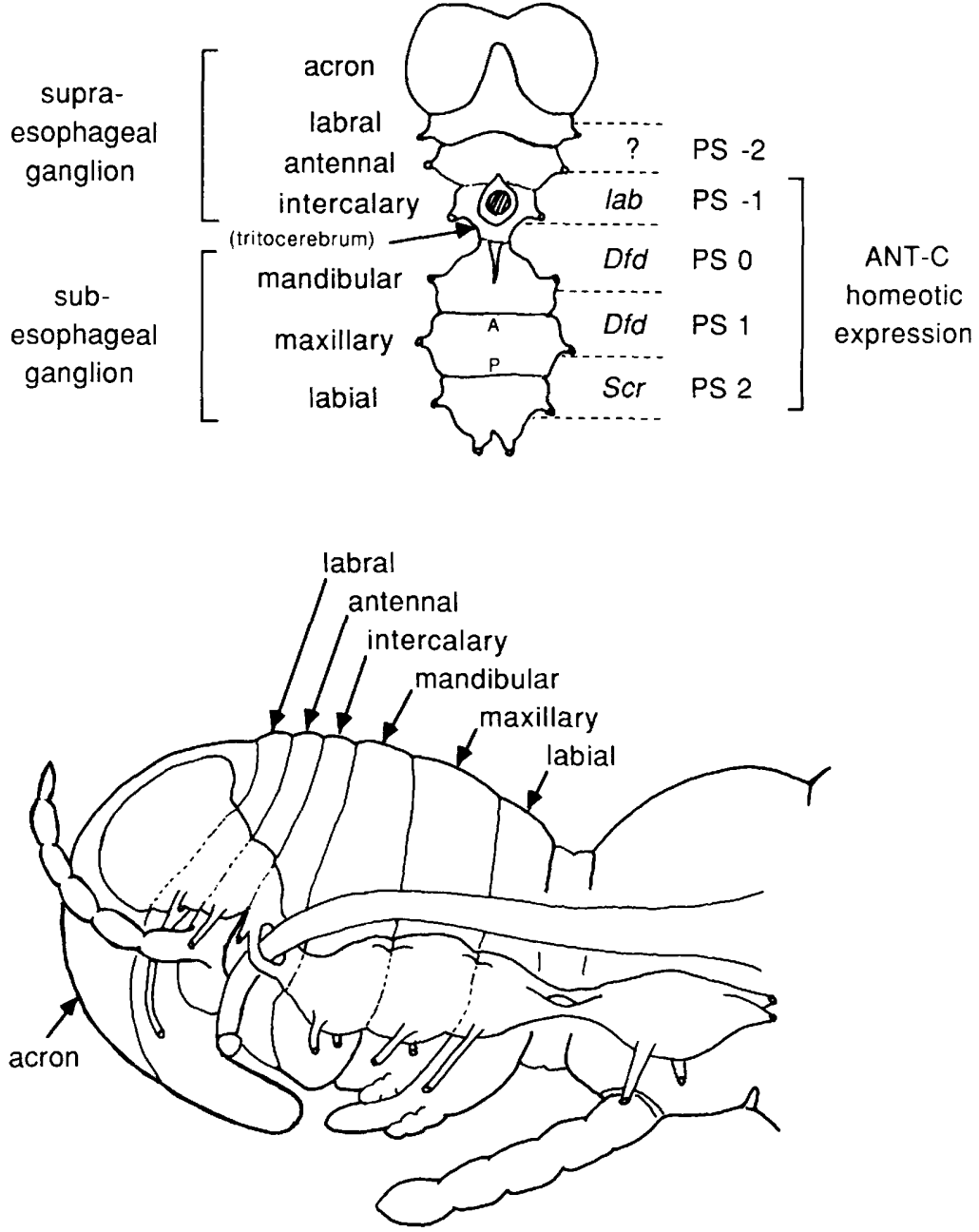

eral observations support this view. First, lab-expressing cells are closely associated with the posterior and lateral margins of the stomodeum. This area corresponds roughly to the position of the intercalary segment in other insects (Rempel and Church 1969; Anderson 1973|. Second, the presumptive neural cells that delaminate from this area of the ectoderm (Figs. 5F and 6C) will constitute a region of the CNS that lies between the respective origins of the antennal and maxillary nerves in the supraesophageal and subesophageal ganglia (Fig. 7A,B,E; Campos-Ortega and Hartenstein 1985). This region corresponds to the tritocerebrum, a derivative of the intercalary segment (Anderson 1973; Rempel 1975), and is depicted schematically in Figure 8 . Third, doublelabeling for $e n$ and $l a b$ expression has shown that two areas of en-expressing cells on either side of the procephalon provide striking boundaries for the domains of $l a b$ expression (Mahaffey et al. 1989). The ventral boundary comprises two small clusters of $e n$-expressing cells (labeled Hy? in Figs. 2 and 3, Mahaffey et al. 1989; see also Dinardo et al. 1985) that are posterior to the stomodeum but anterior to the mandibular-associated stripe of $e^{+}$cells. Therefore, using en expression as a criterion for the position of segmental boundaries, this places $l a b$ expression within the intercalary segment.
Figure 8. ANT-C homeotic gene expression relative to current views of the segmental organization of the insect head. (Bottom) Diagram of the insect head (redrawn from Rempel 1975), showing the acron (nonsegmented) and segmental fusions, which are regarded to have occurred during the evolution of the insect head. (Top) Schematic drawing of the CNS of the insect head (redrawn from Rempel 1975). (Left) The segmental origins of the neuromeres that have fused to form the supraesophageal ganglion (brain) and the subesophageal ganglion. The esophagus intersects the tritocerebrum, the neuromere of the intercalary segment. (Right) The homeotic genes of the ANT-C that are expressed in the head are shown next to their corresponding parasegmental (PS) domains (nonoverlapping) of expression. The exception is the $p b$ gene (not shown), which is expressed throughout most of the length of the CNS in a small number of cells per segment (see Pultz et al. 1988; Mahaffey et al. 1989). (A,P) Anterior and posterior segmental compartments, respectively. Although the domain of $l a b$ expression (PS-1) in the CNS is depicted in a parasegmental register, this assignment should be regarded as tentative; however, a parasegmental register has been observed in the CNS for both Dfd and Scr expression (Chadwick and McGinnis 1987; Mahaffey and Kaufman 1987; Martinez-Arias et al. 1987; Riley et al. 1987; Carroll et al. 1988; Jack et al. 1988; Mahaffey et al. 1989). (?) A postulated ancestral domain of expression for a hypothetical homeotic gene.

Although the presumption has been that the hypopharyngeal lobes represent vestiges of an intercalary segment (Jürgens et al. 1986), our observations argue against this. As the hypopharynx widens during stages 10-11 (Fig. $5 \mathrm{C}, \mathrm{D}, \mathrm{H})$, the two clusters of en-expressing cells spread laterally with the lab-expressing domains (see Mahaffey et al. 1989); the hypopharyngeal lobes will emerge medially (Turner and Mahowald 1979) and do not appear to associate with these en-expressing cells. Further investigation of the fate of these cells has revealed that they delaminate from the ectoderm and incorporate into the CNS just posterior to (and may overlap) the lab-expressing domains of the CNS $(R$. Diederich and T. Kaufman, unpubl.). Thus, the regions of lab expression at the edges of the stomodeum appear to represent the true vestiges of an intercalary segment.

The order in which the homeotic genes of the ANT-C are arranged on the chromosome matches the anteriorposterior order of their embryonic domains of expression (the exception is $p b$; see Pultz et al. 1988). This relationship is diagramed in Figure 8 for the CNS of the head. As the most proximal member of the ANT-C, lab is the most anteriorly expressed of the homeotic loci (both in the CNS and epidermis|. If current views of the segmental organization of the insect head are correct, as 
molecular data seem to suggest, then the prediction is that other homeotic loci, as yet undiscovered, should have domains of expression corresponding to the remaining ancestral regions of the procephalon. Interestingly, this prediction may be fulfilled by the gene, fork head $(f k h)$. A recent developmental genetic analysis by Jürgens and Weigel (1988) suggests that $f k h$ is a homeotic gene whose domain of activity is anterior to that of $l a b$.

\section{Methods}

\section{DNA isolation and Southern analysis}

The methods used for isolating DNA were as described in Scott et al. (1983). This included $\lambda$ phage DNA from genomic (Maniatis et al. 1978) and cDNA (Poole et al. 1985) libraries and whole-genome DNA from stocks of mutant (with balancer chromosomes) and parental (wild-type) flies. To map the position of mutant breakpoints, whole-genome DNA was restricted with at least three different restriction enzymes, size-fractionated in agarose gels, blotted onto Nytran (Schleicher and Schuell), and probed with ${ }^{32}$ P-labeled genomic DNA in the form of $\lambda$ clones or smaller plasmid subclones. Restriction site polymorphisms contained within balancer chromosome sequences were accounted for by including on Southem blots DNA from flies heterozygous for the balancer chromosome and $D f(3 R) S c r$, which deletes most sequences of the ANT-C, including those shown in Figure 1.

\section{RNA isolation and Northern analysis}

The isolation and fractionation of RNA were as described in Pultz et al. (1988). The sizes of transcripts were determined by comparison to transcripts of known size (RNA Ladder, Bethesda Research Laboratories). The DNA probe hybridized to the Northern blot of Figure 4 consisted of the gel-purified 1.7kb EcoRI insert of the cDNA, E7 : Gl. Radioactive labeling (sp. act. $\left.\sim 7 \times 10^{8} \mathrm{cpm} / \mu \mathrm{g}\right)$ and hybridization conditions were as described in Pultz et al. (1988).

The direction of transcription for the two transcription units proximal to $l a b$ was determined by synthesizing strand-specific RNA probes from genomic DNA templates and hybridizing them to Northem blots. A 3.75-kb EcoRI (approximately - 140 to -136.5$)$ fragment and a $0.95-\mathrm{kb} B a m H I(-135$ to -134$)$ fragment were subcloned into Bluescribe plasmid vectors (Stratagene). Synthesis of radioactively labeled RNA transcripts and hybridization conditions were as described in Pultz et al. (1988).

\section{DNA Sequencing}

The DNA sequence shown in Figure 2 was determined by the dideoxy method of Sanger et al. (1977), using ${ }^{35}$ S-labeled dATP. Genomic and cDNA restriction fragments were subcloned into Bluescribe or Bluescript plasmid vectors (Stratagene). Overlapping deletions of the inserted fragments were generated using restriction sites within the cloned insert and the plasmid polylinker and by the exonuclease III-mung bean nuclease method described by Stratagene.

\section{Transcript mapping}

The genomic fragments used in both the S1 nuclease protection and primer extension reactions (see Fig. 3) were labeled at their 5 ' termini with $\left[\gamma^{-32}\right.$ P]ATP (New England Nuclear), using T4 polynucleotide kinase (New England Biolabs), and strand sepa- rated according to the procedures of Maniatis et al. (1982). S1 mapping was performed according to the protocol of Favaloro et al. (1980), except that the single-stranded probes $\left(5 \times 10^{4}\right.$ to $9 \times 10^{4} \mathrm{cpm}$, Cerenkov) were hybridized individually to $5-10$ $\mu \mathrm{g}$ poly $(\mathrm{A})^{+}$embryonic RNA in a $30-\mu$ l volume using $50 \%$ formamide and an annealing temperature of $44^{\circ} \mathrm{C}$. The protected fragments were fractionated electrophoretically on $4-5 \%$ polyacrylamide $-8 \mathrm{M}$ urea gels. For primer extension, $\sim 8 \times 10^{4} \mathrm{cpm}$ (Cerenkov) of the 61-nucleotide PvuII-SacII primer were hybridized to poly $(\mathrm{A})^{+}$embryonic RNA in a $10 \mu \mathrm{l}$ volume containing $50 \%$ formamide, $300 \mathrm{~mm} \mathrm{NaCl}, 10 \mathrm{~mm}$ Tris (pH 7.5), $1 \mathrm{~mm}$ EDTA, and 20 units RNasin (Promega Biotec). After heating to $85^{\circ} \mathrm{C}$ for $15 \mathrm{~min}$, this mixture was incubated at $50^{\circ} \mathrm{C}$ overnight and then ethanol precipitated. The RNA-DNA pellet was resuspended in a $100-\mu \mathrm{l}$ volume containing $50 \mathrm{mM}$ Tris ( $\mathrm{pH} 8.2$ ), $10 \mathrm{~mm} \mathrm{DTT}, 30 \mathrm{mM} \mathrm{NaCl}, 0.5 \mathrm{~mm}$ each deoxyNTP, $6 \mathrm{mM} \mathrm{MgCl} 2,120$ units of RNasin, and 36 units of reverse transcriptase (Seikagaku). Following $1 \mathrm{hr}$ of incubation at $37^{\circ} \mathrm{C}$, the reaction products were ethanol precipitated and resolved on a $5 \%$ polyacrylamide $-8 \mathrm{M}$ urea gel.

\section{Construction and expression of the $\beta$-galactosidase-lab gene fusion}

A 1.33-kb XbaI-XmaI fragment (position 1314-2641, Fig. 2), resulting from a complete $X b a I$ digest and a partial $X m a I$ digest of the cDNA E7 : G1, was subcloned into the polylinker of the plasmid expression vector pWR590-2 (Guo et al. 1984). The resulting gene fusion encoded 599 amino acids of $\beta$-galactosidase, 8 amino acids from the polylinker, and 271 amino acids of the $l a b$ protein. The plasmid was expressed in $E$. coli JM101 by growing the cells overnight in L-Broth and $75 \mu \mathrm{g} / \mathrm{ml}$ ampicillin, with no induction of the lac operon. The cells were pelleted, resuspended in ice-cold phosphate-buffered saline (one-fortieth the culture volumel, and sheared mechanically by passage through a French press. The cell lysate was treated with DNase I (Sigma; $10 \mu \mathrm{g} / \mathrm{ml}, 30 \mathrm{~min}$ on ice) and centrifuged $(35,000 \mathrm{~g}, 1$ $\mathrm{hr}$ ). The resulting pellet was resuspended in sample buffer (onefortieth the initial culture volume; Laemmli 1970), boiled for $30 \mathrm{~min}$, and stored frozen. Partial purification of the fusion protein was as described in Mahaffey and Kaufman (1987).

\section{Preparation and purification of antibodies}

The partially purified fusion protein was injected into New Zealand white rabbits, and anti-l $a b$ antibodies were affinity purified from the immune serum after four boosts. These procedures are described in detail in Mahaffey and Kaufman (1987).

\section{Immunological staining}

Ore-R P2 embryos were fixed and stained as described in Mahaffey and Kaufman (1987), with the following modifications. After embryos had been washed of excess $l a b$ antibodies, they were incubated with biotinylated goat anti-rabbit secondary antibodies (Cappel; preabsorbed to Drosophila embryos) for $2 \mathrm{hr}$, washed for $1-2 \mathrm{hr}$, and incubated for $1 \mathrm{hr}$ with a HRP-biotinavidin complex prepared at one-ninth the concentration recommended by the manufacturer (Vector Labs). Following a 2-hr wash, the staining of the embryos in $0.5 \mathrm{mg} / \mathrm{ml}$ diaminobenzidine and $0.003 \%$ hydrogen peroxide was visually monitored and then terminated by washing. Embryos were dehydrated in an ethanol series, cleared in methyl salicylate, and photographed under Nomarski optics on a Zeiss Photoscope III. The photographs of Figures 5-7 were taken originally on Kodak VRG 100 color print film. Black-and-white prints were obtained using Kodak Panalure II RC paper and a green filter to increase 
the contrast of the reddish-brown staining pattern. The use of the biotin-avidin-HRP complex, as opposed to directly coupled HRP secondary antibodies, significantly improved the signal of $l a b$-specific staining over background staining and allowed us to detect faint lab staining during earlier stages (stage 8) of embryogenesis (not shown).

\section{Acknowledgments}

We thank Larry Kauvar and Tom Kornberg for the cDNA library and Rudi Turner for the SEMs. Dave Cribbs provided advice on the molecular characterization portion of this work, as well as helpful comments on the manuscript. We are grateful to Jim Mahaffey for advice on immunological staining. This research was supported by National Institutes of Health (NIH) grant PHS RO1GM-2499 to T.C.K.. R.J.D. was supported by a $\mathrm{NIH}$ predoctoral training grant in Molecular and Cellular Biology (GM-07227), and V.K.L.M. and M.A.P., by NIH predoctoral training grants (GM-7757) in Genetics. National Science Foundation grant PCM82-12660 provided the scanning electron microscope.

\section{Note}

Sequence data described in this paper have been submitted to the EMBL/GenBank Data Libraries.

\section{References}

Anderson, D.T. 1972. The development of holometabolous insects. In Developmental systems: Insects. (ed. S.J. Counce and C.H. Waddington), vol. 1., pp. 165-242. Academic Press, London.

- Pterygote insects. In Embryology and phylogeny in annelids and arthropods, pp. 209-262. Pergamon Press, Oxford.

Baker, N.E. 1987. Molecular cloning of sequences from wingless, a segment polarity gene in Drosophila: the spatial distribution of a transcript in embryos. EMBO /. 6: 1765-1773.

Localization of transcripts from the wingless gene in whole Drosophila embryos. Development 103: 289-298.

Baumgartner, S., D. Bopp, M. Burri, and M. Noll. 1987. Structure of two genes at the gooseberry locus related to the paired gene and their spatial expression during Drosophila embryogenesis. Genes Dev. 1: 1247-1267.

Bender, W., M. Akam, F. Karch, P.A. Beachy, M. Peifer, P. Spierer, E.B. Lewis, and D.S. Hogness. 1983. Molecular genetics of the bithorax complex in Drosophila melanogaster. Science 221: 23-29.

Berleth, T., M. Burri, G. Thoma, D. Bopp, S. Richstein, G. Frigerio, M. Noll, and C. Nüsslein-Volhard. 1988. The role of localization of bicoid RNA in organizing the anterior pattern of the Drosophila embryo. EMBO 1 . 7: 1749-1756.

Campos-Ortega, J.A. and V. Hartenstein. 1985. The embryonic development of Drosophila melanogaster. Springer-Verlag, Berlin.

Carroll, S.B., S. DiNardo, P.H. O'Farrell, R.A.H. White, and M.P. Scott. 1988. Temporal and spatial relationships between segmentation and homeotic gene expression in Drosophila embryos: Distribution of the fushi tarazu, engrailed, Sex combs reduced, Antennapedia, and Ultrabithorax proteins. Genes Dev. 2: 350-360.

Cavener, D.R. 1987. Comparison of the consensus sequence flanking translational start sites in Drosophila and vertebrates. Nucleic Acids Res. 15: 1353-1361
Chadwick, R. and W. McGinnis. 1987. Temporal and spatial distribution of transcripts from the Deformed gene of Drosophila. EMBO J. 6: 779-789.

Chen, T.-Y. 1929. On the development of imaginal buds in normal and mutant Drosophila melanogaster. $/$. Morphol. 47: 135-199.

Coleman, K.G., S.J. Poole, M.P. Weir, W.C. Soeller, and T. Kornberg. 1987. The invected gene of Drosophila: Sequence analysis and expression studies reveal a close kinship to the engrailed gene. Genes Dev. 1: 19-28.

Darnell, J.E. 1982. Variety in the level of gene control in eukaryotic cells. Nature 297: 365-371.

Dinardo, S., J.M. Kuner, J. Theis, and P.H. O'Farrell. 1985. Development of embryonic pattern in $\mathrm{D}$. melanogaster as revealed by accumulation of the nuclear engrailed protein. Cell 43: 59-69.

Doyle, H., K. Harding, T. Hoey, and M. Levine. 1986. Transcripts encoded by a homeo box gene are restricted to dorsal tissues of Drosophila embryos. Nature 323: 76-79.

Favaloro, J., R. Treisman, and R. Kamen. 1980. Transcription maps of polyoma virus-specific RNA: analysis by two-dimensional nuclease S1 gel mapping. Methods Enzymol. 65: $718-749$.

Frederick R.D. and R.E. Denell. 1982. Embryological origin of the antennomaxillary complex of the larva of Drosophila melanogaster meigen (Diptera: Drosophilidae). Int. J. Insect Morphol. Embryol. 11: 227-233.

Frigerio, G., M. Burri, D. Bopp, S. Baumgartner, and M. Noll. 1986. Structure of the segmentation gene paired and the Drosophila PRD gene set as part of a gene network. Cell 47: 735-746.

Frohnhöfer, H. and C. Nüsslein-Volhard. 1986. Organization of the anterior pattern in the Drosophila embryo by the maternal gene bicoid. Nature 324: 120-125.

Garber, R.L., A. Kuroiwa, and W.J. Gehring. 1983. Genomic and cDNA clones of the homeotic locus Antennapedia in Drosophila. EMBO I. 2: 2027-2034.

Guo, L.-H., P.P. Stępień, J.Y. Tso, R. Brousseau, S. Narang, D. Y. Thomas, and R. Wu. 1984. Synthesis of human insulin gene VIII. Construction of expression vectors for fused proinsulin production in Escherichia coli. Gene 29: 251-254.

Hartenstein, V. 1988. Development of Drosophila larval sensory organs: Spatiotemporal pattern of sensory neurones, peripheral axonal pathways and sensilla differentiation. Development 102: 869-886.

Hoey, T., H.J. Doyle, K. Harding, C. Wedeen, and M. Levine. 1986. Homeo box expression in anterior and posterior regions of the Drosophila embryo. Proc. Natl. Acad. Sci. 83: 4809-4813.

Hultmark, D., R. Klemenz, and W.J. Gehring. 1986. Translational and transcriptional control elements in the untranslated leader of the heat-shock gene hsp22. Cell 44: 429-438.

Jack, T., M. Regulski, and W. McGinnis. 1988. Pair-rule segmentation genes regulate the expression of the homeotic selector gene, Deformed. Genes Dev. 2: 635-651.

Jürgens, G. 1987. Segmental organisation of the tail region in the embryo of Drosophila melanogaster. Wilhelm Roux's Arch. Dev. Biol. 196: 141-157.

Jürgens, G., R. Lehmann, M. Schardin, and C. Nüsslein-Volhard. 1986. Segmental organization of the head in the embryo of Drosophila melanogaster. Wilhelm Roux's Arch. Dev. Biol. 195: 359-377.

Jürgens, G. and D. Weigel. 1988. Terminal versus segmental development in the Drosophila embryo: The role of the homeotic gene fork head. Wilhelm Roux's Arch. Dev. Biol. 197: 345-354. 
Kaufman. T.C. 1978. Cytogenetic analysis of chromosome 3 in Drosophila melanogaster: Isolation and characterization of four new alleles of the proboscipedia $(p b)$ locus. Genetics 90: 579-596.

Kaufman, T.C., R. Lewis, and B. Wakimoto. 1980. Cytogenetic analysis of chromosome 3 in Drosophila melanogaster. The homeotic gene complex in polytene interval 84A-B. Genetics 94: 115-133.

Kuroiwa, A., U. Kloter, P. Baumgartner, and W.J. Gehring. 1985. Cloning of the Sex combs reduced gene in Drosophila and in situ localization of its trancripts. EMBO J. 4: 3757-3764.

Laemmli, U.K. 1970. Cleavage of structural proteins during the assembly of the head of bacteriophage T4. Nature 227: 680685.

Laughon, A. and M.P. Scott. 1984. Sequence of a Drosophila segmentation gene: Protein structure homology with DNAbinding proteins. Nature 310: $25-31$.

Lewis, E.B. 1978. A gene complex controlling segmentation in Drosophila. Nature 276: 565-570.

Lewis, R.A., T.C. Kaufman, R.E. Denell, and P. Tallerico. 1980a. Genetic analysis of the Antennapedia gene complex (ANT-C) and adjacent chromosomal regions of Drosophila melanogaster. I. Polytene chromosome segments 84B-D. Genetics 95: 367-381.

Lewis, R.A., B.T. Wakimoto, R.E. Denell, and T.C. Kaufman. 1980b. Genetic analysis of the Antennapedia gene complex (ANT-C) and adjacent chromosomal regions of Drosophila melanogaster. II. Polytene chromosome segments 84A-84B1,2. Genetics 95: 383-397.

Mahaffey, J.W. and T.C. Kaufman. 1987. Distribution of the Sex combs reduced gene products in Drosophila melanogaster. Genetics 117: 51-60.

- The homeotic genes of the Antennapedia complex and bithorax complex of Drosophila melanogaster. In Developmental Genetics of Higher Organisms, pp. 329-360. Macmillan, New York.

Mahaffey, J.W., R.J. Diederich, and T.C. Kaufman. 1989. Novel patterns of homeotic protein accumulation in the head of the Drosophila embryo. Development 105: 167-174.

Maniatis, T., E.F. Fritsch, and J. Sambrook. 1982. Molecular cloning: A laboratory manual. Cold Spring Harbor Laboratory, Cold Spring Harbor, New York.

Maniatis, T., R.C. Hardison, E. Lacy, J. Lauer, C. O'Connell, D. Quon, G.K. Sim, and A. Efstratiadis. 1978. The isolation of structural genes from libraries of eucaryotic DNA. Cell 15: $687-701$.

Martinez-Arias, A., P.W. Ingham, M.P. Scott, and M.E. Akam. 1987. The spatial and temporal deployment of $D f d$ and $S c r$ transcripts throughout development of Drosophila. Development 100: 673-683.

McGinnis, W., R. Garber, J. Wirz, A. Kuroiwa, and W. Gehring. 1984. A homologous protein-coding sequence in Drosophila homeotic genes and its conservation in other metazoans. Cell 37: 403-409.

Merrill, V.K.L., F.R. Turner, and T.C. Kaufman. 1987. A genetic and developmental analysis of mutations in the Deformed locus in Drosophila melanogaster. Dev. Biol. 122: 379-395.

Meyerowitz, E.M. and D.S. Hogness. 1982. Molecular organization of a Drosophila puff site that responds to ecdysone. Cell 28: $165-176$.

Mlodzik, M., A. Fjose, and W.J. Gehring. 1988. Molecular structure and spatial expression of a homeobox gene from the $1 a-$ bial region of the Antennapedia-complex. EMBO I. 7: 25692578.

Mount S.M. 1982. A catalogue of splice junction sequences. Nucleic Acids Res. 10: 459-472.
O'Connell, P. and M. Roshbash. 1984. Sequence, structure, and codon preference of the Drosophila ribosomal protein 49 gene. Nucleic Acids Res. 12: 5495-5513.

Poole, S.J., L.M. Kauvar, B. Drees, and T. Kornberg. 1985. The engrailed locus of Drosophila: structural analysis of an embryonic transcript. Cell 40: 37-43.

Proudfoot, N.J. and G.G. Brownlee. 1976. 3' Non-coding region sequences in eukaryotic messenger RNA. Nature 262: $211-$ 214.

Pultz, M.A., R.J. Diederich, D.L. Cribbs, and T. C. Kaufman. 1988. The proboscipedia locus of the Antennapedia Complex: A molecular and genetic analysis. Genes Dev. 2:901920.

Regulski, M., K. Harding, R. Kostriker, F. Karch, M. Levine, and W. McGinnis. 1985. Homeo box genes of the Antennapedia and bithorax complexes of Drosophila. Cell 43: 71-80.

Regulski, M., N. McGinnis, R. Chadwick, and W. McGinnis. 1987. Developmental and molecular analysis of Deformed: A homeotic gene controlling Drosophila head development. EMBO I. 6: 767-777.

Rempel, J.G. 1975. The evolution of the insect head: the endless dispute. Quaest. Entomol. 11: 7-25.

Rempel, J.G. and N.S. Church. 1969. The embryology of Lytta viridana Le Conte (Coleoptera: Meloidae). V. The blastoderm, germ layers, and body segments. Can. I. Zool. 47: $1157-1171$.

Riley, P.D., S.B. Carroll, and M.P. Scott. 1987. The expression and regulation of Sex combs reduced protein in Drosophila embryos. Genes Dev. 1:716-730.

Rushlow C., H. Doyle, T. Hoey, and M. Levine. 1987. Molecular characterization of the zerknüllt region of the Antennapedia gene complex in Drosophila. Genes Dev. 1: 1268 1279.

Sánchez-Herrero, E., I. Vernós, R. Marco, and G. Morata. 1985. Genetic organization of Drosophila bithorax complex. $\mathrm{Na}$ ture 313: $108-113$.

Sanger, F., S. Nicklen, and A.R. Coulson. 1977. DNA sequencing with chain-terminating inhibitors. Proc. Natl. Acad. Sci. 74: 5463-5467.

Scott, M.P. and A.J. Weiner. 1984. Structural relationships among genes that control development: Sequence homology between the Antennapedia, Ultrabithorax, and fushi tarazu loci of Drosophila. Proc. Natl. Acad. Sci. 81: 4115-4119.

Scott, M.A., A.J. Weiner, B.A. Polisky, T.I. Hazelrigg, V. Pirotta, F. Scalenghe, and T.C. Kaufman. 1983. The molecular organization of the Antennapedia locus of Drosophila. Cell 35:763-776.

Struhl, G. 1981. A blastoderm fate map of compartments and segments of the Drosophila head. Dev. Biol. 84: 386-396.

Technau, G.M. and J.A. Campos-Ortega. 1985. Fate-mapping in wild-type Drosophila melanogaster. Wilhelm Roux's Arch. Dev. Biol. 194: 196-212.

Turner, F.R. and A.P. Mahowald. 1977. Scanning electron microscopy of Drosophila melanogaster embryogenesis. II. Gastrulation and segmentation. Dev. Biol. 57: 403-416.

- Scanning electron microscopy of Drosophila melanogaster embryogenesis. III. Formation of the head and caudal segments. Dev. Biol. 68: 96-109.

Wakimoto, B.T., F.R. Turner, and T.C. Kaufman. 1984. Defects in embryogenesis in mutants associated with the Antennapedia gene complex of Drosophila melanogaster. Dev. Biol. 102: $147-172$.

Wharton, K.A., B. Yedvobnick, V.G. Finnerty, and S. ArtavanisTsakonas. 1985. opa: A novel family of transcribed repeats shared by the Notch locus and other developmentally regulated loci in D. melanogaster. Cell 40: 55-62. 


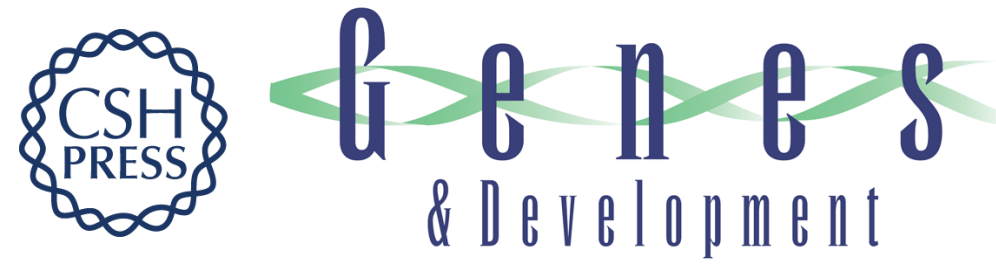

\section{Isolation, structure, and expression of labial, a homeotic gene of the Antennapedia Complex involved in Drosophila head development.}

R J Diederich, V K Merrill, M A Pultz, et al.

Genes Dev. 1989, 3:

Access the most recent version at doi:10.1101/gad.3.3.399

References This article cites 61 articles, 18 of which can be accessed free at:

http://genesdev.cshlp.org/content/3/3/399.full.html\#ref-list-1

License

Email Alerting

Service

Receive free email alerts when new articles cite this article - sign up in the box at the top right corner of the article or click here.

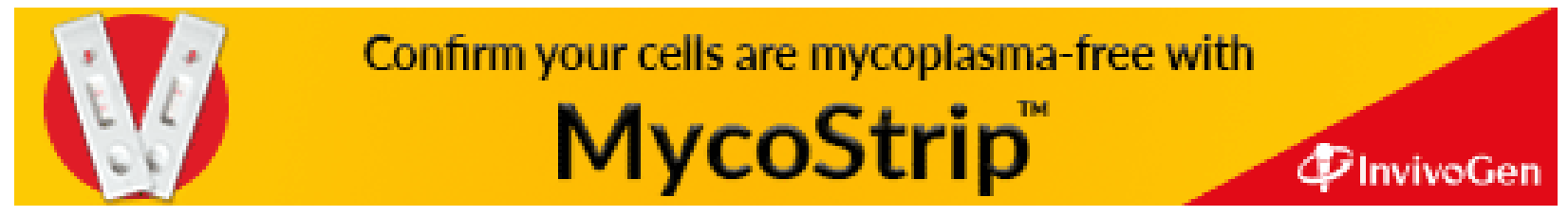

